\title{
Comparative Geochemical Study of the Tertiary and Quaternary Lavas of Western Senegal and the Cape Verde Islands: Geodynamic Implications
}

\author{
Diomaye Yatte $^{{ }^{*}}$, Dinna Pathé Diallo ${ }^{1}$, Ibrahima Sagna ${ }^{2}$ \\ ${ }^{1}$ Département de Géologie, Université Cheikh Anta Diop, Dakar, Sénégal \\ ${ }^{2}$ Institut Fondamental d’Afrique Noire (IFAN), Université Cheikh Anta Diop, Dakar, Sénégal \\ Email: *milandiomaye@yahoo.fr, diallodp@yahoo.fr, isagna@yahoo.fr \\ Received 12 September 2015; accepted 15 November 2015; published 18 November 2015 \\ Copyright (C) 2015 by authors and Scientific Research Publishing Inc. \\ This work is licensed under the Creative Commons Attribution International License (CC BY). \\ http://creativecommons.org/licenses/by/4.0/

(c) $\underset{\mathrm{EY}}{(1)}$ Open Access

\section{Abstract}

The western area of Senegal was the site of a basic volcanism in the Tertiary and Quaternary. That volcanism had caused the formation of alkaline olivine basalts, basanites and nephelinites from microlitic and porphyritic texture to dolerite texture. The geochemistry of major elements shows that the Quaternary basalts are more aluminous and more siliceous, but they contain less magnesium, less iron and less calcium than the Tertiary basalts. Two types of basalt occur here, based on the characteristics of the major elements in the Tertiary lavas: the highly undersaturated basalts of the Cape Verde Peninsula and the slightly undersaturated basalts of the Thiès Plateau. The characteristics of the trace elements reveal shallow interactions due to the contamination and/or assimilation, and to the fractional crystallization, but not due to the heterogeneity of the source. The strong enrichment in light rare earth elements (LREE) and the slight enrichment in heavy rare earth elements (HREE), the anomalies which are negative in $\mathrm{K}$ and $\mathrm{Pb}$ and positive in $\mathrm{Nb}$, Ta and Eu of the Tertiary and Quaternary basalts of Western Senegal and similar anomalies of the same elements ( $\mathrm{Pb}$ not analyzed) described in the Cape Verde islands, allow us to establish links between the petrogenetic mechanisms that had caused the formation of the basalts of this Islands and Western Senegal. Moreover, the volcanic activity in Western Senegal (of continental Intraplate type) and that of the Cape Verde Islands (oceanic intraplate type) are probably related to the hot spot located on the vertical of the Cape Verde.

\section{Keywords}

Western Senegal, Basalts, Tertiary, Quaternary, Cape Verde

\footnotetext{
${ }^{*}$ Corresponding author.
}

How to cite this paper: Yatte, D., Diallo, D.P. and Sagna, I. (2015) Comparative Geochemical Study of the Tertiary and Quaternary Lavas of Western Senegal and the Cape Verde Islands: Geodynamic Implications. International Journal of Geosciences, 6, 1193-1213. http://dx.doi.org/10.4236/ijg.2015.611094 


\section{Introduction}

The Tertiary volcanism (the Thiès Plateau and the Cape Verde Peninsula) and the Quaternary volcanism (Cape Verde Peninsula) in the western part of Senegal allowed the formation of alkaline rocks (Dia, [1]; Lo, [2]. Lo et al., [3]). Many studies have been conducted on the spatial distribution of volcanic products, the relationship between volcanism and tectonics in addition to the geodynamic evolution of this area (Lompo, [4]; Lo et al. [3]. Mellet, [5] Crévola et al. [6]). These studies have brought to light the formation process, the petrographic features and their relationship with the periods of magmatic activity. However, little research has been done on the petrogenesis and the geodynamic evolution of the Tertiary and Quaternary lavas, or on the geochemical evolution which has resulted in magmatic associations. The location of the Cape Verde Islands near the coast of Senegal suggests that there might be a similarity between the volcanism of these islands and the volcanism of Western Senegal. The transversal fractures have caused the North-West-South-East volcanic alignements together with the North-East-South-West alignments which are observed in the Archipelago. The only active volcano in the archipelago (Fogo) is close to the Vema fault whose possible extension to Senegal through the submarine Cayar Canyon could link it to the volcanism of Western Senegal. In this context a comparative study of the Tertiary and Quaternary volcanism should allow firstly, to compare the basalts of Western Senegal in terms of their geochemistry, and secondly, to have an idea about the petrogenetic links with the volcanism of the Cape Verde islands.

This study aims, from the recent geochemical data, to determine the petrogenesis of Western Senegal's basalts and the type of volcanism involved. The main geochemical data collected as well as the geodynamic context of the Cape Verde Peninsula and the Thiès Plateau will be compared to the data collected from the Cape Verde Islands. The results are discussed and compared with the two alkaline provinces of the Cameroon and Ethiopian rift.

\section{Geological Framework}

Unlike the rest of the Senegal-Mauritania basin, the geological history of the Senegalese basin is rather complex, on the one hand from a lithostratigraphic, petrographic, and tectonic perspective and on the other hand, from a geodynamic perspective.

\subsection{Lithostratigraphy}

The lithostratigraphy of the Cape Verde Peninsula was established from the data collected during research surveys on water or hydrocarbons, but also from outcrops observations. Thus, three formations have been identified.

a) Mesozoic Age Formations

- The Trias and Lias are characterized by the existence of salt-bearing rocks. They are associated with black and green clays, pyrite and sulfur, siderite crystals and rare quartz grains (Templeton, [7]).

- The Jurassic is characterized by allochemical carbonate sediments in the West and detrital sediments in the East. The microfauna and microflora are very diverse (lamellibranch moluscs, gastropods, echinoderms and bryozoans, algae). The carbonates form a thick series stretching along West Africa's margin.

- The Lower Cretaceous is characterized by the appearance of detritus in the West, despite the predominance of carbonate deposits. A series consisting of sandstones alternates with silty clays. Its thickness decreases eastwards. In the West occur carbonate facies alternating with sandstone rocks. Ostracods, pollen, many Choffatella decipiens and microplankton are observed.

- The Middle Cretaceous is characterized by detritus invading the basin. The facies that existed in the Cretaceous are still persistent. Throughout the study area, the limestones are dominant and are dated using Nummulites. The facies observed there are limestone clays, sandy limestone, clay or silica of variable thickness.

- The Upper Cretaceous is characterized by limestone facies, limestone clays or marly limestone often containing phosphate and planktonic microfauna that consists of Globorotalia cocoansis and Globigerapsis semi involuta and Catapsydrax unicavus. At the end of the Cretaceous, a thick sandy clay deposit was formed on the impermeable base. These sands contain large amounts of water used throughout the basin.

b) The Tertiary Formations

They include the following formations: 
- The Lower Paleocene consists of clayey marl, calcareous marl and clays (the Madeleines Inlet). It is ten meters thick at the outcrop and over 200 meters deep. It contains a wildlife that consists of Globigerina and Globorotalia.

- The Upper Paleocene includes silicified clay called "Hospital formation" that outcrops at the Pointe Bernard, at the Pointe Diop, at the Madeleines Inlet and the Pointe de l'Abattoir (Bongrand and Elouard [8]). Its thickness decreases from the North to the South of the head of the Cape Verde Peninsula.

- The Lower Eocene corresponds to the calcareous clay (attapulgite) of the Dakar prison. It contains a micro-fauna with Globorotalia and Cibicides.

- The Middle Eocene is basically formed with yellow to gray marly clay, with a rich microfauna consisting of Robulusincisus, Cyroidinasenegalensis and Epinideselel'atus (Bernard Beach, Bargny). Then the calcareous marl of the Bernard Beach appears.

- The Upper Eocene outcrops nowhere in the head of the peninsula. It was observed in a single survey conducted in Yoff and is entitled DK2. It is formed by a beige clay with a rich fauna consisting of uvigerina.

The Tertiary is characterized by a continental episode with intense volcanism that gave birth to many types of rocks (the tuffs of the Madeleines and the ankaratrite and basanite flows). The dating of these rocks revealed an age between $48 \mathrm{Ma}$ and $5.30 \mathrm{Ma}$ (Cantagrel et al. [9]; Sarr et al. [10]). These volcanic formations are covered by a laterite surface which marks the end of the Tertiary and the beginning of the Quaternary.

c) The Quaternary Formations

They are represented by marine, continental and volcanic facies.

The marine Quaternary is characterized by two episodes:

- The Inchirien represented by a beach-rock (Southeast Bargny) dated 32,000 years by K/Ar method;

- The Nouakchottian (6800 - 4200 years by K/Ar method) is characterized by accumulations of shells (Cape Verde Peninsula and the Tamna Lake) and a more humid climate. During that period, the sea flowed into all the depressions to form a series of shallow bays with Anadara senilis shells accumulations (Elouard et al. [11]).

The Continental Quaternary is represented by shell glazes and alluvial terraces. The glazes are sometimes polygenic. The Continental Quaternary ends with aeolian deposits covering large areas with an ancient erg (Akcharien), red dunes (Ogolian) and yellow and white dunes forming a coastal strip between Dakar and Saint Louis. The quaternary volcanic activities that are observed at the outcrop are located in the head of the Cape Verde Peninsula.

\subsection{Geographical Distribution and Petrography of Western Senegal's Volcanism}

The volcanism of Western Senegal is represented by small outcrops which are distributed between the Cape Verde Peninsula (Dakar) and the Thiès plateau. It covers an area of 325,500 $\mathrm{km}^{2}$ (Figure 1). The outcrops are in the form of lava flows, veins, dykes, and tuffs. Tertiary volcanic rocks are distributed throughout the outcrop area while those of the Quaternary volcanism are located in the northwestern tip of the Cape Verde Peninsula. There is also evidence of volcanism in boreholes. Tertiary volcanic rocks are represented by olivine basanites, olivine alkali basalts and nephelinites. Their texture ranges from the fine microlitic porphyry-type (nephelinites basanites and olivine) to the subdoleritic type (alkaline olivine basalts to medium grain) (Dia, [1]; Lo, [2]). Those features reflect a petrographic evolution from nephelinites to medium-grained alkali olivine basalts. The Quaternary volcanic rocks include alkali olivine basalts and olivine basanites with fine to coarse grain. (Dia, [1]; Lo, [2]). Their texture is either microlitic porphyry (some alkali olivine basalts and some olivine basanites) or doleritic (coarse-grained alkaline olivine basalts). They evolved from olivine basanites to coarse-grained alkali olivine basalts (Dia, [1]; Lo, [2]). This evolution also resulted in a decrease in the content of mafic minerals and mesostasis (olivine and pyroxene). The Quaternary lava are therefore more differentiated.

\subsection{Tectonics}

Three categories of deep faults have been described (Dia, [1]; Lo, [2]; Crévola et al. [6]. Mpassi, [12]). The first one, well represented at the horst of Diass, is oriented North-South. It corresponds to the ancient fractures hemming the blocks that were tilted during the rifting coinciding with the opening of the Atlantic Ocean. The second one, which is oriented East-West, cuts across the eastern part of the study area. This type of transform faults is related to the Mid-Atlantic Ridge (Bellion and Crévola, [13]). The third category, which is oriented North-West- 


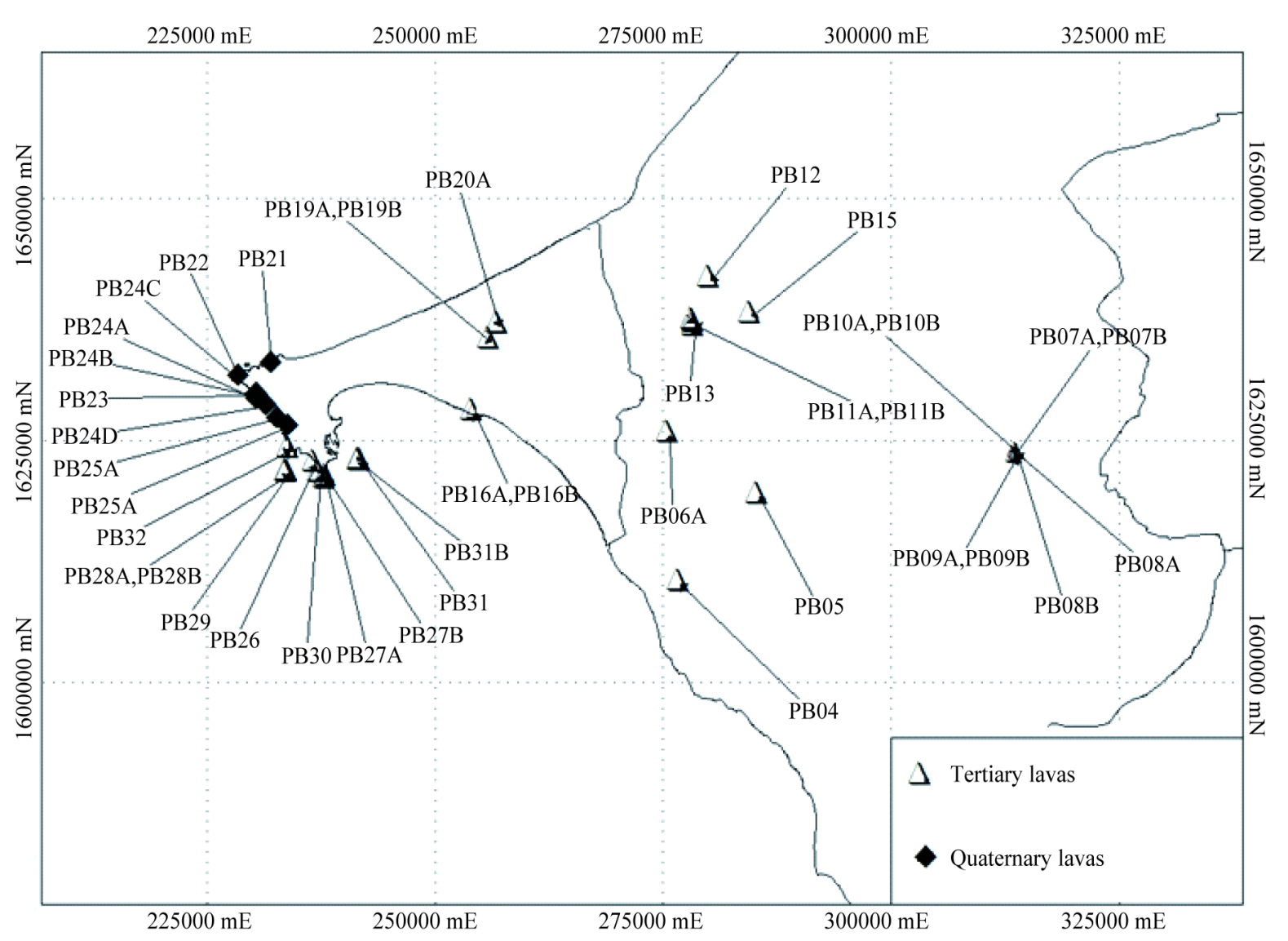

Figure 1. Location map of sampling sites in the study Cape Verde Peninsula and Thies plateau.

South-East, affects the western part of the Cape Verde Peninsula. All these faults probably had a real impact and could have caused the quaternary volcanism of the head of the Cape Verde Peninsula (Dia, [1]).

\section{Methodology and Results of the Study}

Based on the cartographic resources of Senegal's basin, we carried out a sampling on various volcanic sites in Western Senegal (veins, dykes and sometimes flows shaped like basalt columns) in order to collect the representative facies that shall be geochemically analyzed using whole rock samples. The concentrations of the major elements of the Tertiary and Quaternary volcanic samples were determined at ALS Laboratory Group in Sevilla, Spain using the ICP-AES method. The ICP-MS method was used for both trace elements and rare earths. The results are shown in Tables 1-3.

\section{Analysis and Discussion of Results}

\subsection{Geochemistry of Major Elements}

The average contents of the major elements of Western Senegal's Quaternary lavas (Table 1) show that they are highly under-saturated in silica $\left(\mathrm{SiO}_{2}\right.$ average around $\left.44.7 \%\right)$, with high levels of sodium $\left(3.64 \%\right.$ of $\mathrm{Na}_{2} \mathrm{O}$ on average), medium levels of potassium ( $0.91 \%$ of $\mathrm{K}_{2} \mathrm{O}$ on avarage), high levels of calcium $(11.65 \%$ of $\mathrm{CaO}$ on average), high levels of magnesium (around $10.42 \%$ of $\mathrm{MgO}$ on average) and high levels of iron (11.81\% of $\mathrm{Fe}_{2} \mathrm{O}_{3}$ on average). The Tertiary lavas of the Thiès Plateau (Table 2) are slightly under-saturated in silica (an average of $45.5 \%$ ), with higher concentrations of alumina (an average of $13.52 \%$ ), more sodium (an average of around $4.11 \%$ ) and more potassium (with $1.22 \%$ on average), but with less iron (10.78\% on average), less magnesium (8.55\% of $\mathrm{Mg}$ on average) and lower contents of calcium (10.61\% on average) than those of the Cape Verde Peninsula $\left[\mathrm{SiO}_{2} \sim 43.95 \%\right)\left(\mathrm{Al}_{2} \mathrm{O}_{3} \sim 12.51 \%\right)\left(\mathrm{Fe}_{2} \mathrm{O}_{3} \sim 11.73 \%\right)(\mathrm{MgO} \sim 11.12 \%)(\mathrm{CaO} \sim 12.04 \%)\left(\mathrm{Na}_{2} \mathrm{O}\right.$ 
Table 1. Major (wt\%), Trace (ppm) and Rares Earth (ppm) elements concentrations of the Quaternary lavas of Western Senegal (Cape Verde Peninsula). K/Ar ages are from Crévola et al. (1994).

\begin{tabular}{|c|c|c|c|c|c|c|c|c|c|c|c|c|c|c|c|c|c|c|c|c|c|c|}
\hline Sample & $\mathrm{SiO}_{2}$ & $\mathbf{A l}_{2} \mathbf{O}_{3}$ & $\mathrm{Fe}_{2} \mathrm{O}_{3}$ & $\mathrm{CaO}$ & MgO & $\mathrm{Na}_{2} \mathrm{O}$ & $\mathbf{K}_{2} \mathbf{O}$ & $\mathrm{Cr}_{2} \mathrm{O}_{3}$ & $\mathrm{TiO}_{2}$ & MnO & $\mathbf{P}_{2} \mathbf{O}_{5}$ & LOI & Total & $\mathbf{R b}$ & Ba & Th & $\mathbf{U}$ & Nb & Ta La & Ce & & Nd \\
\hline PB21 & 54 & 14.8 & 10.5 & 8.79 & 6.9 & 4 & 0.57 & 0.04 & 1.46 & 0.14 & 0.28 & 0.25 & 101 & 13.4 & 265 & 2.7 & 0.6 & 31 & 1.524 & 39.9 & 4.6 & 18 \\
\hline PB22 & 53 & 14.5 & 10.7 & 8.84 & 6.5 & 3.96 & 0.51 & 0.04 & 1.47 & 0.14 & 0.3 & 0.43 & 99.9 & 111 & 251 & 2.6 & 0.6 & 35 & 1.723 & 41.9 & 4.8 & 19 \\
\hline PB24A & 54 & 14.6 & 10.4 & 8.25 & 6.6 & 4.32 & 0.8 & 0.03 & 1.67 & 0.14 & 0.39 & -0.1 & 101 & 19.3 & 337 & 4 & 0.7 & 41 & 231 & 55.2 & 6 & 23 \\
\hline PB24B & 49 & 14.5 & 10.4 & 7.69 & 6.9 & 4.14 & 2 & 0.03 & 2.24 & 0.14 & 0.74 & 2.36 & 99.9 & 62.6 & 662 & 5.1 & 1.2 & 73 & 4.839 & 73.2 & 8.6 & 35 \\
\hline PB24C & 49 & 14.5 & 10.7 & 7.94 & 8.3 & 4.87 & 1.72 & 0.04 & 2.23 & 0.14 & 0.52 & 0.36 & 101 & 49.9 & 585 & 3.9 & 0.9 & 62 & 4.129 & 53.7 & 6.4 & 26 \\
\hline PB24D & 50 & 14.4 & 11 & 8.44 & 8.9 & 4.18 & 1.21 & 0.04 & 1.83 & 0.15 & 0.54 & 0.53 & 101 & 33.2 & 473 & 4 & 0.9 & 55 & 3.233 & 60.6 & 7.3 & 28 \\
\hline PB25A & 49 & 14.7 & 10.5 & 8.07 & 7.8 & 4.58 & 1.54 & 0.03 & 1.96 & 0.15 & 0.61 & 0.78 & 100 & 46.3 & 563 & 4.9 & 1.1 & 62 & 3.935 & 64.8 & 7.5 & 30 \\
\hline PB25B & 53 & 14.6 & 10.3 & 8.61 & 5.7 & 4.01 & 0.52 & 0.03 & 1.64 & 0.12 & 0.35 & 1.33 & 100 & 12.1 & 289 & 3.6 & .0 .8 & 38 & 1.830 & 51.2 & 5.9 & 23 \\
\hline
\end{tabular}

\begin{tabular}{|c|c|c|c|c|c|c|c|c|c|c|c|c|c|c|c|c|c|c|c|c|c|c|c|c|}
\hline Sample & Sr & Sm & $\mathbf{Z r}$ & Eu & Gd & Tb I & Dy 1 & Ho Y & $\mathbf{Y} \mathbf{E}$ & $\mathbf{r} \mathbf{T n}$ & & Yb & Lu & $\mathrm{Cr}$ & V & Co & $\mathbf{N i}$ & Sc & $\mathbf{P b}$ & $\mathrm{FeO} / \mathrm{MgO}$ & Mg\# & $\begin{array}{l}\text { Ages } \mathrm{K} / \mathrm{Ar} \\
\text { en Ma }\end{array}$ & \multicolumn{2}{|c|}{ Location } \\
\hline PB21 & 450 & 4 & 84 & 1.6 & 4.5 & 0.73 & 3.60 & 0.72 & 201. & 80. & & .26 & 0.18 & 310 & 153 & 40 & 143 & 16 & 2 & 1.36 & 0.58 & $1.1 \pm 0.05$ & & \\
\hline PB22 & 443 & 4.4 & 88 & 1.6 & 4.6 & 0.73 & 3.60 & 0.72 & 201. & $\begin{array}{ll}7 & 0 .\end{array}$ & & .19 & 0.19 & 290 & 153 & 42 & 141 & 16 & 3 & 1.48 & 0.57 & $1.05 \pm 0.2$ & $\begin{array}{l}\text { C } \\
\text { A }\end{array}$ & $\mathbf{P}$ \\
\hline PB24A & 467 & 4.9 & 100 & 1.9 & 5.1 & 0.73 & 3.90 & 0.72 & 201. & 80. & & 1.3 & 0.19 & 240 & 149 & 37 & 111 & 15 & 4 & 1.42 & 0.58 & $1.05 \pm 0.2$ & $\mathbf{P}$ & \\
\hline PB24B & 860 & 7.4 & 192 & 2.7 & 6.9 & 0.94 & 4.50 & 0.82 & 211. & $\begin{array}{ll}7 & 0 .\end{array}$ & & .05 & 0.14 & 210 & 149 & 38 & 170 & 10 & 3 & 1.35 & 0.62 & $1.05 \pm 0.2$ & & \\
\hline PB24C & 687 & 6 & 161 & 2.3 & 6.2 & 0.94 & 4.20 & 0.82 & 211. & 80. & & .15 & 0.16 & 290 & 154 & 43 & 217 & 12 & 2 & 1.16 & 0.63 & $1.05 \pm 0.2$ & $\begin{array}{l}\mathbf{V} \\
\mathbf{E}\end{array}$ & S \\
\hline PB24D & 688 & 6.1 & 140 & 2.2 & 5.9 & 0.84 & 4.1 & 0.82 & 221. & $\begin{array}{ll}9 & 0 .\end{array}$ & & .29 & 0.18 & 320 & 161 & 44 & 256 & 14 & 3 & 1.11 & 0.61 & $0.57 \pm 0.04$ & R & L \\
\hline PB25A & 768 & 6.3 & 167 & 2.4 & 6.2 & 0.84 & $4.4 \mathrm{C}$ & 0.82 & 221. & 90. & & 1.3 & 0.19 & 270 & 160 & 40 & 195 & 12 & 4 & 1.21 & 0.54 & $0.57 \pm 0.04$ & $\mathbf{E}$ & A \\
\hline PB25B & 459 & 5 & 100 & 1.9 & 5.4 & 0.84 & 4.2 & 0.82 & 232 & 0 & & .44 & 0.22 & 260 & 160 & 32 & 109 & 16 & 4 & 1.63 & 0.77 & & & \\
\hline
\end{tabular}

3.47\%), $\left.\left(\mathrm{K}_{2} \mathrm{O} \sim 0.79 \%\right)\right]$. The Quaternary lavas (Table 1) are slightly more differentiated than the Tertiary lavas (Table 2) if we consider the geochemistry of the major elements. They are slightly undersaturated in silica (49.85\%), with high concentrations of sodium (3.89\%), calcium (9.08\%), and medium concentrations of magnesium (8.35\%) and iron (10.62\%).

The descriptions of the major elements show:

- Higher contents of $\mathrm{SiO}_{2}$ in the Quaternary lavas compared to the Tertiary lavas. The Tertiary lavas of the Thiès Plateau are richer in silica than the Tertiary lavas of the Cape Verde Peninsula. The basalts of the Cape Verde Islands (Table 4) have lower contents of silica than those of Western Senegal;

- High contents of $\mathrm{Al}_{2} \mathrm{O}_{3}$ in the Tertiary lavas compared to the Quaternary lavas. In addition, the Tertiary lavas of Western Senegal have higher levels of alumina in the Thiès Plateau than in the Cape Verde Peninsula. In the Cape Verde Islands, the Quaternary basalts are more aluminous than the Tertiary basalts of these islands (Doucelance et al., [14]) and those of Western Senegal. The latter are more aluminous than the Tertiary basalts of the Cape Verde Islands;

- Relatively low $\mathrm{MgO}, \mathrm{FeO}$ and $\mathrm{CaO}$ contents in the Tertiary lavas, the latter containing lower levels of magnesium, iron and calcium in Thiès Plateau than in the Cape Verde Peninsula. The Tertiary basalts of the Cape Verde Islands contain higher concentrations of magnesium and calcium than the lavas of Western Senegal. The Quaternary lavas of these islands contain lower concentrations of magnesium, but they have iron and calcium contents that are higher than in the Quaternary volcanic rocks of Western Senegal;

- and a relatively slight variation of $\mathrm{Na}_{2} \mathrm{O}$ and $\mathrm{K}_{2} \mathrm{O}$ between the Tertiary and Quaternary lavas of Western Senegal and those of the Cape Verde Islands (Figure 2).

These different features reveal two groups in the Tertiary lavas of Western Senegal: the group of the Cape Verde Peninsula Tertiary basalts (40\% - 52\% in silicia with an average of $44.23 \%)$ and the group of the Thiès Plateau Tertiary basalts (43\% - 49\% in silicia with an average of $45.6 \%$ ). The basalts of the Cape Verde Islands (Doucelance et al., [14]) are more undersaturated with silica than those of Western Senegal (Figure 2). 
Table 2. Major (wt\%), Trace (ppm) and Rares Earth (ppm) elements concentrations of the Tertiary lavas of Western Senegal (Cape Verde Peninsula and Thiès Plateau). K/Ar ages are from Crévola et al. (1994).

\begin{tabular}{|c|c|c|c|c|c|c|c|c|c|c|c|c|c|c|c|c|c|c|c|c|c|c|}
\hline Impl & $\mathrm{O}_{2}$ & $\mathrm{Al}_{2} \mathbf{O}_{3}$ & ${ }_{2} \mathbf{O}_{3}$ & & gO & $\mathbf{O}$ & $\mathrm{K}_{2} \mathrm{O}$ & $\mathrm{r}_{2} \mathrm{O}_{3}$ & $\mathrm{TiO}_{2}$ & & $\mathbf{P}_{2} \mathbf{O}_{5}$ & & To & $\mathbf{R b}$ & Ba & Th & $\mathbf{U}$ & $\mathbf{N b}$ & Ta La & $\mathrm{Ce}$ & Pr Nd & . \\
\hline & & 126 & & & & & & & & & & & & & & & 0.8 & 52 & & & 6.427 & 553 \\
\hline & & & & & & & & & & & & & & & & & 0.9 & 56 & 3.931 & & 8 & \\
\hline & & & & & & & & & & & & & & & & & 1 & & & & & \\
\hline & & & & & & & & & & & & & & & & & 1 & 55 & & 63.6 & 7.430 & \\
\hline 09A & & & & & & & & & & & & & & & & & & 107 & & 69.8 & 833 & 69 \\
\hline В09B & & & & & & & & & & & & & & & 808 & & & 151 & & & 1040 & 10 \\
\hline B10A & & & & & & & & & & & & & & & & & 1.3 & 94 & & & 9.841 & \\
\hline B10B & & & & & & & & & & & & & & & & & & 89 & & & & 54 \\
\hline $310 \mathrm{C}$ & & & & & & & & & & & & & & & & & & 77 & & 78.3 & 937 & \\
\hline PB01 & 40 & & & & & & & & & & & & & & & & & 103 & & 145 & 1665 & 12 \\
\hline PB04 & 42 & & & & & & & & & & & & & & 795 & & 2.91 & 118 & & 161 & 1869 & 11 \\
\hline PB05 & 41 & & & & & & & & & & & & & & 83 & & & 108 & & 154 & 1769 & 12 \\
\hline B06A & & & & & & & & & & & & & & & & & & 95 & & & 40 & \\
\hline B11A & & & & & & & & & & & & & & & & & 0.7 & 41 & & 47.8 & 5.825 & \\
\hline B11B & 4 & & & & & & & & & & & & & 14 & & & & 44 & & 50 & 626 & \\
\hline PB12 & 47 & & & & & & & & & & & & & & & & 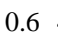 & 43 & & 49.1 & 6.226 & \\
\hline PB13 & 45 & & & & & & & & & & & & 99. & & 565 & & 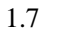 & 85 & & 97.3 & 1246 & \\
\hline PB14 & & & & & & & & & & & & & & & 313 & & 0. & 47 & & 57.1 & $7 \quad 29$ & \\
\hline PB15 & & & & & & & & & & & & & & & 2 & & 0.7 & 33 & 220 & & 4.820 & \\
\hline B16A & & & & & & & & & & & & & & & 981 & & 3. & 146 & & 171 & 1970 & 33 \\
\hline B16B & & & & & & & & & & & & & & & & & & 13 & & & 1968 & \\
\hline P10D & & & & & & & & & & & & & & & & & 5.4 & 54 & & & 8.733 & \\
\hline B20A & & & & & & & & & & & & & & & 338 & & 0.7 & 43 & & & 7.329 & \\
\hline B20C & & & & & & & & & & & & & & & 195 & & 4.7 & 44 & 5.23 & 65.9 & 831 & 81 \\
\hline PB26 & & & & & & & & & & & & & & & & & 2.3 & 82 & & & 1661 & \\
\hline B27A & & & & & & & & & & & & & & & 815 & & & 109 & $\begin{array}{ll}7 & 82\end{array}$ & & 1867 & \\
\hline 327B & & & & & & & & & & & & & & & 70 & & & 10 & & & 1762 & \\
\hline B28A & & & & & & & & & & & & & & & 489 & & 1.3 & 84 & & 788.6 & 1040 & \\
\hline PB28B & & & & & & & & & & & & & & & 513 & & 1.41 & 120 & & 933 & 1141 & \\
\hline PB29 & & & & & & & & & & & & & & & & & 3 & 75 & & & 9.637 & \\
\hline PB30 & & & & & & & & & & & & & & & & & & 118 & & & 1041 & \\
\hline BS1A & $4 J$ & & & & & & & & & & & & & & & & 0.6 & 61 & & & 6.32 & \\
\hline (3) & 46 & & & & & & & & & & & & & 28.5 & & & 1 & 92 & & & 9.738 & \\
\hline B31C & 45 & & & & & & & & & & & & & & 347 & 3 & 0.7 & 71 & & & 6.827 & \\
\hline PB? & & & & & & & & & & & & & & & & & 1 & 51 & & & 30 & 5 \\
\hline
\end{tabular}




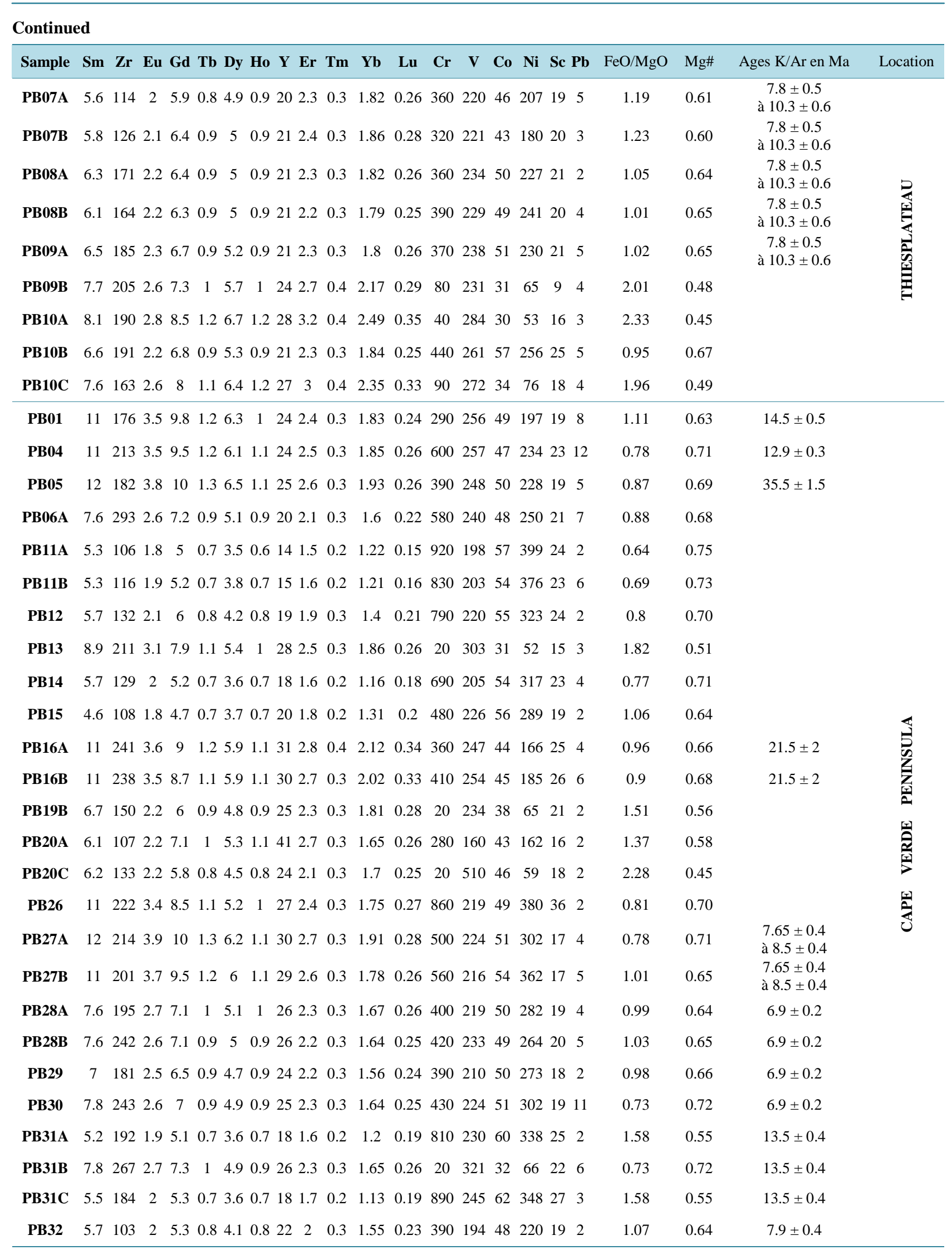


Table 3. CPWI norms of the Tertiary and Quaternary lavas of Western Senegal.

\begin{tabular}{|c|c|c|c|c|c|c|c|c|c|c|c|c|c|c|c|c|c|}
\hline & & $\mathbf{Q}$ & or & ab & an & lc & ne & ac & Di (wo) & Di (en) & Hy (en) & Ol (fo) & Ol (fa) & mt & hem & ap & Totals \\
\hline \multirow{35}{*}{ } & PB01 & 0 & 3.43 & 0 & 15.69 & 0.39 & 15.71 & 0 & 20.7 & 17.85 & 0 & 7.4 & 0 & 0.62 & 13.55 & 2.17 & 95.52 \\
\hline & PB04 & 0 & 0 & 0 & 16.16 & 4.36 & 14.11 & 0 & 22.36 & 19.28 & 0 & 8.5 & 0 & 0.59 & 10.55 & 2.2 & 98.11 \\
\hline & PB05 & 0 & 0 & 0 & 14.12 & 5.75 & 15.52 & 0 & 21.91 & 18.88 & 0 & 8.23 & 0 & 0.63 & 11.37 & 2.22 & 98.64 \\
\hline & PB06A & 0 & 4.4 & 14.37 & 16.46 & 0 & 7.38 & 0 & 17.16 & 14.79 & 0 & 10.3 & 0 & 0.55 & 11.12 & 1.28 & 97.78 \\
\hline & PB07A & 0 & 5.42 & 29.37 & 18.91 & 0 & 0 & 0 & 12.28 & 10.58 & 1.05 & 7.64 & 0 & 0.56 & 11.55 & 0.9 & 98.25 \\
\hline & РB07B & 0 & 5.57 & 28.87 & 18.99 & 0 & 0.75 & 0 & 12.95 & 11.17 & 0 & 7.05 & 0 & 0.55 & 11.27 & 0.97 & 98.14 \\
\hline & PB08A & 0 & 7.82 & 12.88 & 13.79 & 0 & 11.19 & 0 & 15.74 & 13.57 & 0 & 9.16 & 0 & 0.64 & 12.02 & 1.1 & 97.9 \\
\hline & PB08B & 0 & 7.59 & 13.38 & 13.28 & 0 & 11.32 & 0 & 15.57 & 13.42 & 0 & 9.76 & 0 & 0.63 & 11.89 & 1.11 & 97.95 \\
\hline & PB09A & 0 & 7.59 & 9.1 & 12.16 & 0 & 14.2 & 0 & 17.18 & 14.81 & 0 & 8.93 & 0 & 0.67 & 12 & 1.19 & 97.83 \\
\hline & PB09B & 0 & 11.53 & 13.69 & 11.33 & 0 & 21.32 & 0 & 13.61 & 11.73 & 0 & 0.86 & 0 & 0.64 & 11.12 & 1.79 & 97.63 \\
\hline & PB10A & 0 & 9.36 & 28.76 & 15.13 & 0 & 6.12 & 0 & 12.54 & 10.81 & 0 & 0.69 & 0 & 0.6 & 11.79 & 1.56 & 97.38 \\
\hline & PB10B & 0 & 3.79 & 7.93 & 15.13 & 0 & 9.57 & 0 & 19.72 & 17 & 0 & 10.1 & 0 & 0.7 & 12.73 & 1 & 97.64 \\
\hline & PB10C & 0 & 7.71 & 31.19 & 16.36 & 0 & 3.09 & 0 & 12.61 & 10.87 & 0 & 2.15 & 0 & 0.59 & 11.63 & 1.38 & 97.58 \\
\hline & PB11A & 0 & 3.53 & 15.78 & 16.87 & 0 & 3.71 & 0 & 15.48 & 13.35 & 0 & 17.7 & 0 & 0.51 & 10.73 & 0.78 & 98.48 \\
\hline & PB11B & 0 & 3.75 & 15.99 & 17.24 & 0 & 3.84 & 0 & 15.63 & 13.48 & 0 & 16.3 & 0 & 0.53 & 10.88 & 0.8 & 98.4 \\
\hline & PB12 & 0 & 4.48 & 18.76 & 21.05 & 0 & 0 & 0 & 14.21 & 12.25 & 2.18 & 12.6 & 0 & 0.52 & 11.19 & 0.74 & 98.01 \\
\hline & PB13 & 0 & 6.21 & 23.94 & 18.97 & 0 & 8.05 & 0 & 13.75 & 11.85 & 0 & 1.55 & 0 & 0.51 & 11.04 & 1.54 & 97.43 \\
\hline & PB14 & 0 & 3.37 & 18.89 & 19.03 & 0 & 2.92 & 0 & 15.62 & 13.46 & 0 & 13 & 0 & 0.53 & 10.58 & 0.82 & 98.27 \\
\hline & PB15 & 0 & 3.19 & 25.08 & 21.86 & 0 & 0 & 0 & 11.54 & 9.95 & 4.64 & 8.41 & 0 & 0.52 & 12.23 & 0.68 & 98.08 \\
\hline & PB16A & 0 & 0 & 8.56 & 26.09 & 0 & 5.43 & 0 & 20.98 & 18.09 & 0 & 6.57 & 0 & 0 & 12.09 & 0 & 97.8 \\
\hline & PB16B & 0 & 0 & 5.55 & 20.7 & 0 & 11.77 & 0 & 22.54 & 19.43 & 0 & 7.09 & 0 & 0 & 11.83 & 0 & 98.92 \\
\hline & PB19B & 0 & 4.23 & 28.6 & 18.67 & 0 & 5.11 & 0 & 14.07 & 12.13 & 0 & 3.26 & 0 & 0.57 & 10.85 & 0.8 & 98.31 \\
\hline & PB20A & 0.8 & 4.55 & 35.73 & 17.86 & 0 & 0 & 0 & 9.31 & 8.03 & 10.06 & 0 & 0 & 0.52 & 10.63 & 0.87 & 98.36 \\
\hline & PB20C & 0 & 1.97 & 30.63 & 15.52 & 0 & 7.89 & 0 & 13.13 & 11.32 & 0 & 1.76 & 0 & 0.58 & 13.62 & 0.86 & 97.28 \\
\hline & PB26 & 0 & 0.5 & 4.55 & 19.88 & 0 & 4.42 & 0 & 20.24 & 17.44 & 0 & 17.8 & 0 & 0.62 & 10.43 & 2.34 & 98.23 \\
\hline & PB27A & 0 & 0 & 0 & 9.17 & 5.67 & 17.08 & 0 & 22.79 & 19.64 & 0 & 10.3 & 0 & 0.69 & 11.86 & 2.93 & 100.1 \\
\hline & PB27B & 0 & 0 & 0 & 9.24 & 5.45 & 17.12 & 17 & 21.27 & 18.33 & 0 & 12.2 & 0 & 0.68 & 11.99 & 2.63 & 98.91 \\
\hline & PB28A & 0 & 5.84 & 14.85 & 13.05 & 0 & 10.66 & 0 & 15.28 & 13.17 & 0 & 10.2 & 0 & 0.63 & 12.04 & 2.02 & 97.77 \\
\hline & PB28B & 0 & 6.4 & 10.45 & 11.79 & 0 & 13.14 & 0 & 17.07 & 14.72 & 0 & 9.26 & 0 & 0.63 & 11.87 & 2.07 & 97.4 \\
\hline & PB29 & 0 & 5.59 & 16.28 & 12.93 & 0 & 10.65 & 0 & 14.77 & 12.73 & 0 & 10.2 & 0 & 0.63 & 12.07 & 1.93 & 97.82 \\
\hline & PB30 & 0 & 5.87 & 10.96 & 11.7 & 0 & 12.66 & 0 & 16.93 & 14.6 & 0 & 10.2 & 0 & 0.63 & 11.71 & 2.14 & 97.44 \\
\hline & PB31A & 0 & 4.7 & 15.35 & 16.43 & 0 & 3.83 & 0 & 15.36 & 13.24 & 0 & 16.4 & 0 & 0 & 11.96 & 0.79 & 98.07 \\
\hline & PB31B & 0 & 6.9 & 14.85 & 23.27 & 0 & 9.22 & 0 & 16.68 & 14.38 & 0 & 0 & 0 & 0.49 & 9.73 & 1.22 & 96.73 \\
\hline & PB31C & 0 & 5.21 & 11.25 & 16.15 & 0 & 5.59 & 0 & 16.93 & 14.59 & 0 & 15.3 & 0 & 0.55 & 11.44 & 0.82 & 97.86 \\
\hline & PB32 & 0 & 3.68 & 29.57 & 18.54 & 0 & 0 & 0 & 11.76 & 10.14 & 5.74 & 6.09 & 0 & 0.56 & 11.3 & 1.09 & 98.47 \\
\hline \multirow{8}{*}{ 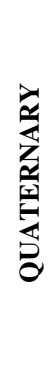 } & PB21 & 4.2 & 3.34 & 33.47 & 20.51 & 0 & 0 & 0 & 8.79 & 7.58 & 9.57 & 0 & 0 & 0.45 & 10.03 & 0.61 & 98.56 \\
\hline & PB22 & 5.3 & 3.06 & 33.97 & 20.56 & 0 & 0 & 0 & 7.5 & 6.46 & 10.01 & 0 & 0 & 0.46 & 10.49 & 0.66 & 98.51 \\
\hline & PB24A & 3.4 & 4.7 & 36.28 & 17.81 & 0 & 0 & 0 & 8.6 & 7.42 & 8.88 & 0 & 0 & 0.45 & 9.97 & 0.85 & 98.34 \\
\hline & PB24B & 0 & 12.16 & 34.07 & 15.32 & 0 & 1.02 & 0 & 8.11 & 7 & 0 & 7.53 & 0 & 0.47 & 10.36 & 1.66 & 97.7 \\
\hline & PB24C & 0 & 10.15 & 30.35 & 12.57 & 0 & 5.81 & 0 & 9.89 & 8.53 & 0 & 8.52 & 0 & 0.46 & 10.36 & 1.13 & 97.78 \\
\hline & PB24D & 0 & 7.16 & 34.43 & 16.79 & 0 & 0.48 & 0 & 9.15 & 7.89 & 0 & 10 & 0 & 0.49 & 10.61 & 1.18 & 98.17 \\
\hline & PB25A & 0 & 9.19 & 33.66 & 14.97 & 0 & 2.92 & 0 & 9.11 & 7.85 & 0 & 8.25 & 0 & 0.49 & 10.25 & 1.34 & 98.03 \\
\hline & PB25B & 6.3 & 3.11 & 34.23 & 20.47 & 0 & 0 & 0 & 8.6 & 7.42 & 6.9 & 0 & 0 & 0.4 & 10.13 & 0.77 & 98.35 \\
\hline
\end{tabular}


Table 4. Compararative table of the major elements concentrations of the Tertiary and Quaternary basalts of Western Senegal (this study) and those of Cape Verde (Fogo, Sal, Sao Nicolau, Sao Vicente and Santiago) (Doucelance et al. [14]).

\begin{tabular}{|c|c|c|c|c|c|c|c|}
\hline \multirow[b]{3}{*}{ Elements (wt\%) } & \multicolumn{2}{|c|}{ Western Senegal } & \multicolumn{5}{|c|}{ Cape Verde Islands } \\
\hline & \multirow{2}{*}{$\begin{array}{l}\text { Tertiary lavas } \\
\quad(\mathrm{n}=34)\end{array}$} & \multirow{2}{*}{$\begin{array}{l}\text { Quaternary } \\
\text { lavas }(n=9)\end{array}$} & \multirow{2}{*}{$\begin{array}{c}\text { Quaternary } \\
\begin{array}{c}\text { Fogo (active Volcan) } \\
{[n=6]}\end{array}\end{array}$} & \multicolumn{4}{|c|}{ Tertiary } \\
\hline & & & & $\begin{array}{l}\text { Sal (50 Ma) } \\
\quad[\mathrm{n}=3]\end{array}$ & $\begin{array}{l}\text { Sao Nicolau } \\
\quad(n=7)\end{array}$ & $\begin{array}{l}\text { Sao Vicente } \\
\quad(n=7)\end{array}$ & $\begin{array}{c}\text { Santiago } \\
(n=5)\end{array}$ \\
\hline $\mathrm{SiO}_{2}$ & $39.9-51.7$ & $40.1-53.6$ & $40.65-42.47$ & $35.67-38.89$ & $39.97-44.47$ & $38.54-44.47$ & $38.08-42.96$ \\
\hline $\mathrm{Al}_{2} \mathbf{O}_{3}$ & $10.75-16.05$ & $9.31-14.8$ & $13.31-15.71$ & $8.25-10.93$ & $11.88-13.87$ & $8.38-13.34$ & $10.22-15.49$ \\
\hline $\mathrm{Fe}_{2} \mathrm{O}_{3}$ & $10.1-13.9$ & $10.3-11.63$ & $13.06-14.19$ & $12.20-13.37$ & $11.59-13.36$ & $12.12-13.52$ & $11.02-12.49$ \\
\hline $\mathrm{CaO}$ & $8.57-15.10$ & $7.69-14.2$ & $11.07-12.81$ & $12.48-16.42$ & $10.81-14.02$ & $9.71-14.17$ & $11.19-14.54$ \\
\hline MgO & $4.62-14.80$ & $5.67-9.81$ & $5.81-9.21$ & $12.90-19.97$ & $10.16-14.20$ & $10.10-18.96$ & $5.82-13.19$ \\
\hline $\mathrm{Na}_{2} \mathrm{O}$ & $2.23-6.05$ & $1.42-4.87$ & $3.08-4.41$ & $1.80-3.07$ & $1.98-3.93$ & $1.19-3.27$ & $1.89-3.16$ \\
\hline $\mathbf{K}_{2} \mathbf{O}$ & $0.23-1.88$ & $0.08-1.72$ & $1.92-2.77$ & $0.93-1.34$ & $0.56-1.13$ & $0.35-1.25$ & $1.23-2.91$ \\
\hline $\mathrm{TiO}_{2}$ & $1.57-2.61$ & $1.46-2.24$ & $3.53-4.40$ & $3.31-3.40$ & $2.71-3.47$ & $2.25-4.42$ & $2.66-3.91$ \\
\hline $\mathbf{P}_{2} \mathbf{O}_{5}$ & $0.34-1.34$ & $0.28-0.74$ & $0.60-0.91$ & $0.48-1.44$ & $0.40-0.79$ & $0.30-0.65$ & $0.48-1.20$ \\
\hline Total & $99.13-101.9$ & $99.9-101.4$ & $99.86-100.88$ & $97.10-99.76$ & $98.82-100.68$ & $96.51-100.85$ & $95.76-99.02$ \\
\hline
\end{tabular}

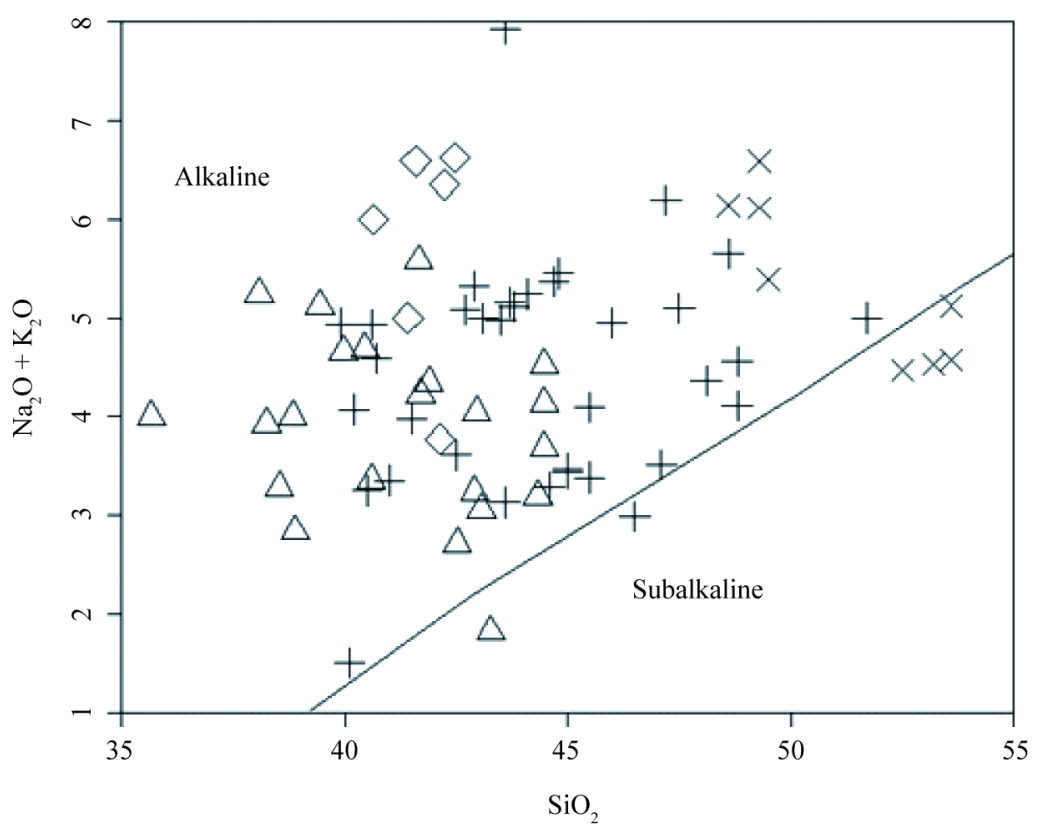

Figure 2. Diagram $\left(\mathrm{Na}_{2} \mathrm{O}+\mathrm{K}_{2} \mathrm{O} / \mathrm{SiO}_{2}\right)$ of Irvine and Baragar [15] of the lavas of the Western Senegal and the basalts of the Cape Verde Islands. This diagram has been realized with the MINPET 2.02 software. +: Tertiary lavas of Western Senegal; ×: Quaternary lavas of Western Senegal; $\Delta$ : Tertiary lavas of the Cape Verde islands; $\diamond$ : Quaternary lavas of the Cape Verde Islands.

The data in Table 4 show, on the one hand, the properties of some major elements in the Tertiary and Quaternary basalts of Western Senegal, and on the other hand, the properties of the Tertiary and quaternary basalts of the Cape Verde Islands.

The variations observed in the lavas of Western Senegal show that the Tertiary basalts have higher magnesium levels, but are more ferriferous, more calcic, less aluminous, and less alkaline than the Quaternary basalts. The latter contain more silica, less alumina, less mafic elements, less potassium and less titanium than the Qua- 
ternary basalts of the Cape Verde Islands. The Tertiary basalts of Western Senegal have higher levels of silica with more sodium, less potassium, less magnesium, less titanium than the Tertiary basalts of those islands. The Tertiary lavas of Western Senegal and those of the islands (Sao Nicolau, Santiago, Sao Vicente and Sal) have all average contents of silica below 45\%. Contrastingly, the Quaternary basalts of Western Senegal have higher concentrations of silica than the Tertiary basalts of Western Senegal or the basalts of the Cape Verde Islands. In the Cape Verde Islands, Doucelance et al. [14] have shown that the average content of magnesium in the Southern islands (Fogo and Santiago) is 7.97\% and the average magnesium content in the northern islands (Sao Vicente, Sao Nicolau and Sal) reaches $13.14 \%$. This shows that the Tertiary basalts (10.42\%) and Quaternary basalts (8.35\%) of Western Senegal have average contents of magnesium between those of the South Islands and North Islands. All these variations reveal that the basalts of the Cape Verde Islands are similar to the basalts of Western Senegal. The lavas of Western Senegal are alkaline to potassic trend. Tertiary lavas of the Cape Verde Islands are alkaline to sodium trend while those Quaternary are alkaline to potassic trend (Figure 3).

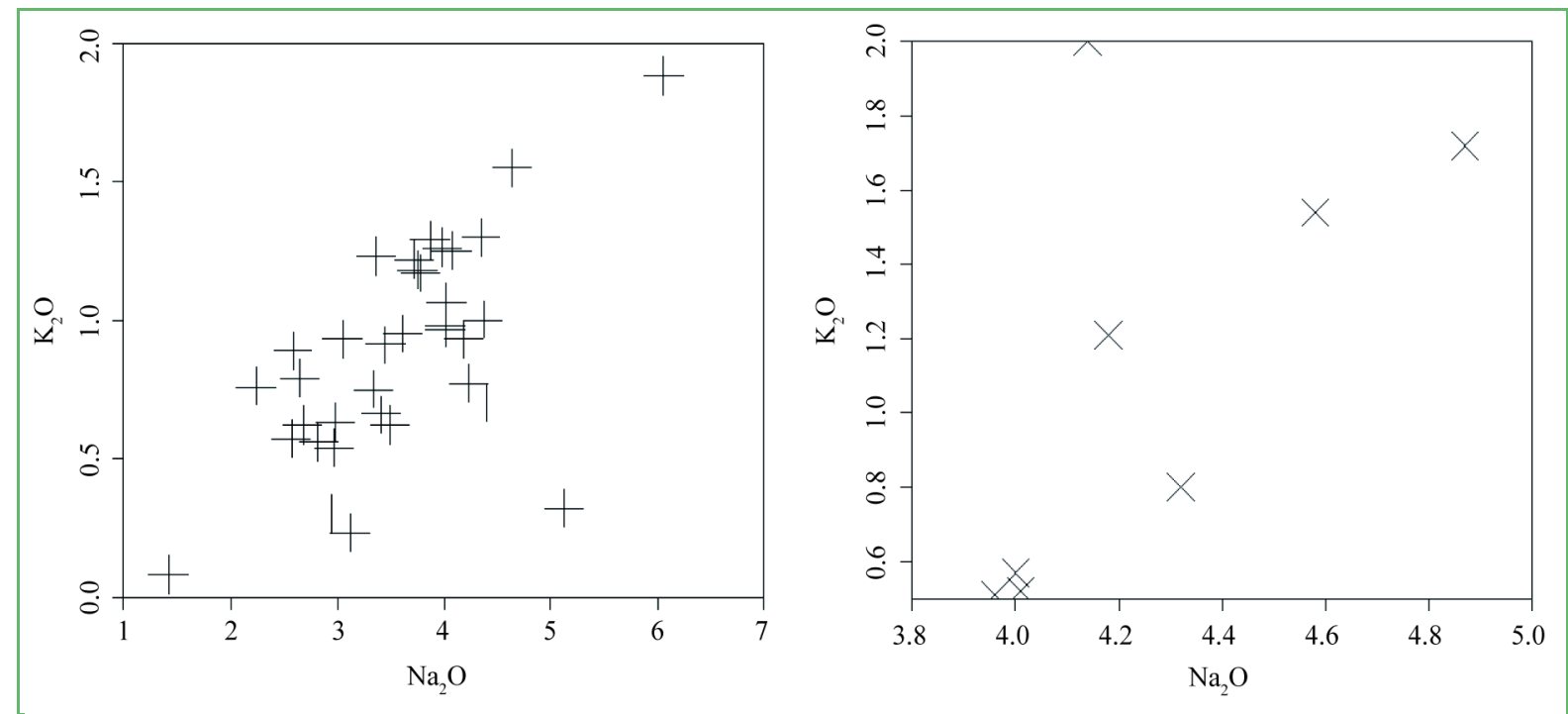

(a)

(b)

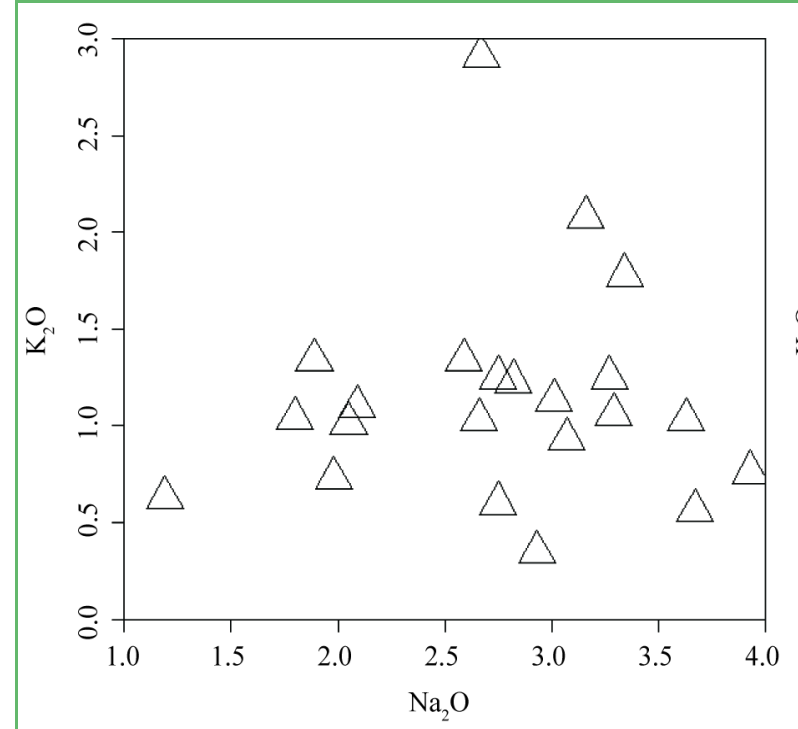

(c)

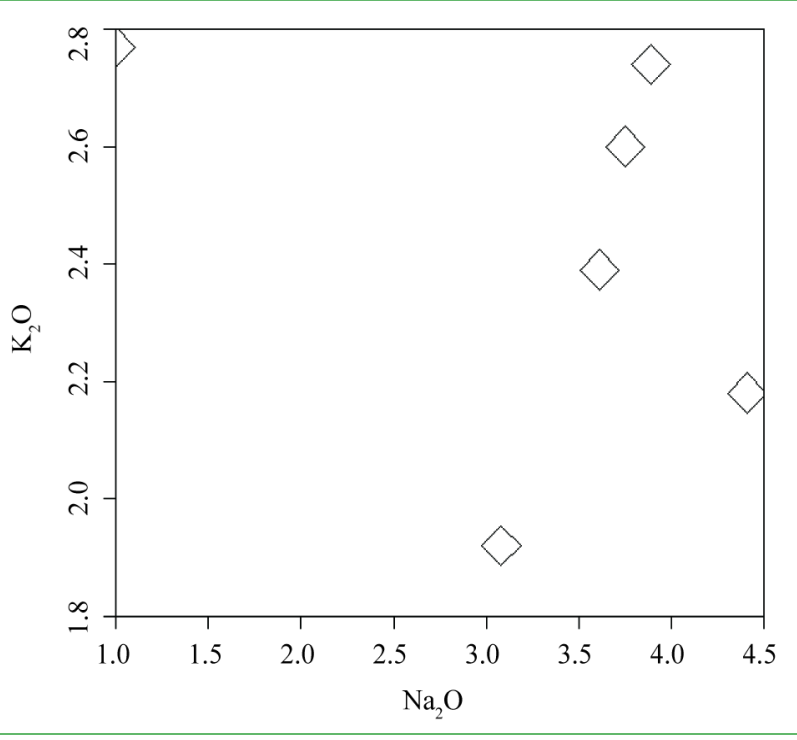

(d)

Figure 3. $\mathrm{Na}_{2} \mathrm{O}$ vs $\mathrm{K}_{2} \mathrm{O}$ of the Tertiary (a) and Quaternary (b) lavas of western Senegal (this study) and those of Tertiary (c) and Quaternary (d) lavas of the Cape Verde islands (Doucelance et al. [14]). 


\subsection{Geochemistry of Trace Elements}

The Tertiary lavas of Western Senegal have very high average levels of compatible elements $(\mathrm{Ni}=223.45 \mathrm{ppm}$, $\mathrm{Cr}=410 \mathrm{ppm}, \mathrm{Co}=47.48 \mathrm{ppm}, \mathrm{V}=244.63 \mathrm{ppm}, \mathrm{Sc}=20.28 \mathrm{ppm})$ and high field strength elements (HFSE) (Nb $=83.84 \mathrm{ppm}, \mathrm{Zr}=180.69 \mathrm{ppm}, \mathrm{Th}=5.60 \mathrm{ppm}, \mathrm{Ta}=5.73 \mathrm{ppm})$. In the Cape Verde Islands, the Tertiary basalts have average contents of compatible elements $(\mathrm{Ni}=266.5 \mathrm{ppm}$, $\mathrm{Co}=59.63 \mathrm{ppm}$; $\mathrm{Cr}, \mathrm{V}$, Sc not determined $)$ and high contents of HFSE $(\mathrm{Nb}=64.95 \mathrm{ppm}, \mathrm{Zr}=250.63 \mathrm{ppm}$, Th $=5.54 \mathrm{ppm}$ and $\mathrm{Ta}=4.67 \mathrm{ppm})$. The average levels of the elements mentioned above referring to the Tertiary basalts of Western Senegal and Cape Verde Islands are higher than those of the oceanic island basalts (OIB), of the enriched (E-MORB) or normal (N-MORB) oceanic plateaus basalts (Sun and McDonough, [16]) [Table 5]. Those high concentrations of compatible and HFS elements give the Tertiary lavas of Western Senegal and of the Cape Verde islands a primary character. The Quaternary basalts of Western Senegal have also very high average contents of compatible elements $(\mathrm{Ni}=194.2 \mathrm{ppm}, \mathrm{Cr}=344 \mathrm{ppm}, \mathrm{Co}=41.3 \mathrm{ppm}, \mathrm{Sc}=165.2 \mathrm{ppm}$ and $\mathrm{V}=16.66 \mathrm{ppm})$ and HFSE $(\mathrm{Nb}=$ $52.87 \mathrm{ppm}, \mathrm{Zr}=135.7 \mathrm{ppm}$, $\mathrm{Th}=4.22 \mathrm{ppm}$ and $\mathrm{Ta}=2.99 \mathrm{ppm})$. In the Cape Verde Islands, the average contents of the compatible elements observed in the Quaternary basalts $(\mathrm{Ni}=60.83 \mathrm{ppm}$, Co $=45.33 \mathrm{ppm})$ and of the HFSE $(\mathrm{Nb}=81.66 \mathrm{ppm}, \mathrm{Zr}=336.5 \mathrm{ppm}$, Th $=3.5 \mathrm{ppm}, \mathrm{Ta}=6.45 \mathrm{ppm})$ are also very high. The Quaternary lavas of Western Senegal and of the Cape Verde Islands display contents that are higher than those of the N-MORB, E-MORB and OIB (Sun and McDonough, [16]) [Table 5]. These lavas reflect the primary feature of the Quaternary lavas of Western Senegal and of the Cape Verde Islands basalts. The Tertiary and Quaternary basalts of Western Senegal and those of the Cape Verde Islands have very high contents of incompatible and

Table 5. Comparative Table of concentrations of trace elements in the basalts of Western Senegal (this study), the Cape Verde Islands (Doucelance et al. [14]), N-MORB, E-MORB and OIB (Sun and McDonough, [16]).

\begin{tabular}{|c|c|c|c|c|c|c|c|c|c|c|}
\hline \multirow{3}{*}{$\begin{array}{l}\text { Traces } \\
\text { elements }\end{array}$} & \multicolumn{2}{|c|}{ Western Senegal } & \multicolumn{5}{|c|}{ Cape Verde Islands } & \multirow{3}{*}{ N-MORB } & \multirow{3}{*}{ E-MORB } & \multirow{3}{*}{ OIB } \\
\hline & \multirow{2}{*}{$\begin{array}{c}\text { Tertiary } \\
\text { lavas }\end{array}$} & \multirow{2}{*}{$\begin{array}{l}\text { Quaternary } \\
\text { lavas }\end{array}$} & \multirow{2}{*}{$\begin{array}{c}\text { Quaternary } \\
\text { Fogo }\end{array}$} & \multicolumn{4}{|c|}{ Tertiary } & & & \\
\hline & & & & Sal & Sao Nicolau & Sao Vicente & Santiago & & & \\
\hline $\mathrm{Rb}$ & $9.5-46.4$ & $11.1-62.6$ & $43-63$ & $25-33$ & $14-30$ & $7.000-27$ & $24-59$ & 0.56 & 5.04 & 31.0 \\
\hline $\mathrm{Ba}$ & $194.5-981$ & $251-662$ & $634-849$ & $352-929$ & $324-534$ & $204-591$ & $561-986$ & 6.30 & 57 & 350 \\
\hline Th & $2.51-11.65$ & $2.58-5.11$ & $4-5.7$ & $3.3-12.2$ & $2.9-7.8$ & $2.3-6$ & $4.6-15.4$ & 0.120 & 0.60 & 4.00 \\
\hline $\mathrm{U}$ & $0.61-5.36$ & $0.62-1.17$ & $0.88-1.25$ & $0.75-2.95$ & $0.67-1.54$ & $0.5-1.08$ & $0.92-4.71$ & 0.047 & 0.18 & 1.02 \\
\hline $\mathrm{Nb}$ & $32.7-120$ & $30.9-72.9$ & $67-90$ & $47-89$ & $48-74$ & $28-73$ & $62-112$ & 2.33 & 8.30 & 48.0 \\
\hline Ta & $2-11.1$ & $1.5-4.8$ & $5.24-7.20$ & $3.40-6.15$ & $3.31-5.15$ & $2.01-5.12$ & $4.39-12.10$ & 0.132 & 0.47 & 2.70 \\
\hline $\mathrm{La}$ & $19.8-91.9$ & $22.5-41.3$ & $45-59$ & $36-92$ & $28-58$ & $22-54$ & $45-132$ & 2.50 & 6.30 & 37.0 \\
\hline Ce & $47.8-171$ & $39.9-73.5$ & $98-131$ & $77-181$ & $64-114$ & $48-112$ & 89 - 252 & 7.50 & 15.0 & 80.0 \\
\hline $\operatorname{Pr}$ & $4.75-19.1$ & $4.56-8.62$ & $11.6-15.7$ & $9.7-21.2$ & $7.8-13.2$ & $5.7-12.6$ & $11.1-29.3$ & 1.32 & 2.05 & 9.70 \\
\hline $\mathrm{Nd}$ & $20.1-69.5$ & $18-34.5$ & $47-64$ & $39-80$ & $31-54$ & $24-54$ & $44-115$ & 7.30 & 9.00 & 38.5 \\
\hline $\mathrm{Sr}$ & $497-3340$ & $443-860$ & $893-1104$ & $643-1515$ & $544-876$ & $348-1026$ & 824 - 2064 & 90 & 155 & 660 \\
\hline $\mathrm{Sm}$ & $4.64-11.4$ & $3.99-7.39$ & $9.1-11.4$ & $8-14.8$ & $6.6-96$ & $5.000-10$ & $8.7-19.4$ & 2.63 & 2.60 & 10.0 \\
\hline $\mathrm{Zr}$ & $106-293$ & 84 - 192 & $281-357$ & $216-301$ & $197-234$ & $142-270$ & $236-502$ & 74 & 73.0 & 280 \\
\hline $\mathrm{Eu}$ & $1.77-3.88$ & $1.61-2.69$ & $2.84-3.70$ & $2.53-4.43$ & $2.09-3.22$ & $1.64-3.02$ & $2.61-5.72$ & 1.02 & 0.91 & 3.00 \\
\hline Gd & $4.7-10.3$ & $4.45-6.87$ & $6.74-9.41$ & $6.65-11.10$ & $5.84-8.52$ & $4.49-8.39$ & $6.47-14.10$ & 3.680 & 2.970 & 7.620 \\
\hline $\mathrm{Tb}$ & $0.65-1.28$ & $0.66-0.89$ & $0.98-1.33$ & $0.89-1.44$ & $0.84-1.17$ & $0.64-1.11$ & $0.98-1.99$ & 0.670 & 0.530 & 1.050 \\
\hline Dy & $3.51-6.68$ & $3.61-4.46$ & $5-6.49$ & $4.32-7.56$ & $4.55-6.16$ & $3.30-5.50$ & $4.81-9.81$ & 4.550 & 3.550 & 5.600 \\
\hline Но & $0.63-1.21$ & $0.68-0.81$ & $0.868-1.120$ & $0.741-1.180$ & $0.852-1145$ & $0.604-1.000$ & $0.820-1.670$ & 1.01 & 0.790 & 1.06 \\
\hline Er & $1.5-3.16$ & $1.72-2.04$ & $2.05-2.64$ & $1.57-3.14$ & $2.09-2.56$ & $1.37-2.21$ & $2-3.85$ & 2.97 & 2.31 & 2.62 \\
\hline $\mathrm{Tm}$ & $0.19-0.41$ & $0.2-0.27$ & $0.271-0.358$ & $0.203-0.346$ & $0.291-0.370$ & $0.228-0.315$ & $0.230-0.530$ & 0.456 & 0.356 & 0.350 \\
\hline $\mathrm{Yb}$ & $1.16-2.49$ & $1.05-1.55$ & $1.80-2.27$ & $1.31-2.48$ & $1.78-2.18$ & $1.24-1.90$ & $1.35-2.88$ & 3.05 & 2.37 & 2.16 \\
\hline $\mathrm{Lu}$ & $0.15-0.35$ & $0.14-0.23$ & $0.251-0.310$ & $0.170-0.323$ & $0.264-0.325$ & $0.197-0.252$ & $0.230-0.453$ & 0.455 & 0.354 & 0.300 \\
\hline
\end{tabular}


HFSE. The Tertiary basalts of Western Senegal and Cape Verde Islands all have contents of these elements that are higher than the contents of the elements of the Quaternary basalts mentioned above. Small variations in the content of these elements were noted between the Tertiary lavas of Western Senegal and those of the Cape Verde Islands. In contrast, the Quaternary basalts of Western Senegal reveal average contents of these elements that are higher than the Quaternary ones in the Cape Verde Islands. This reflects the slightly differentiated nature of the Tertiary lavas in Western Senegal and in the Cape Verde Islands, compared to the type of Quaternary lavas mentioned above. These levels, which are higher than those of the OIB, E-MORB and N-MORB may reflect the contamination of these lavas by the crust that is rich in HFSE.

\subsection{Geochemistry of Rare Earths Elements (REE)}

The C1 chondrite-normalisation patterns (Taylor and McLennan, [17]) of the basalts in Western Senegal and in the Cape Verde Islands (Doucelance et al., [14]) all reveal similar fractionations (Figure 4).

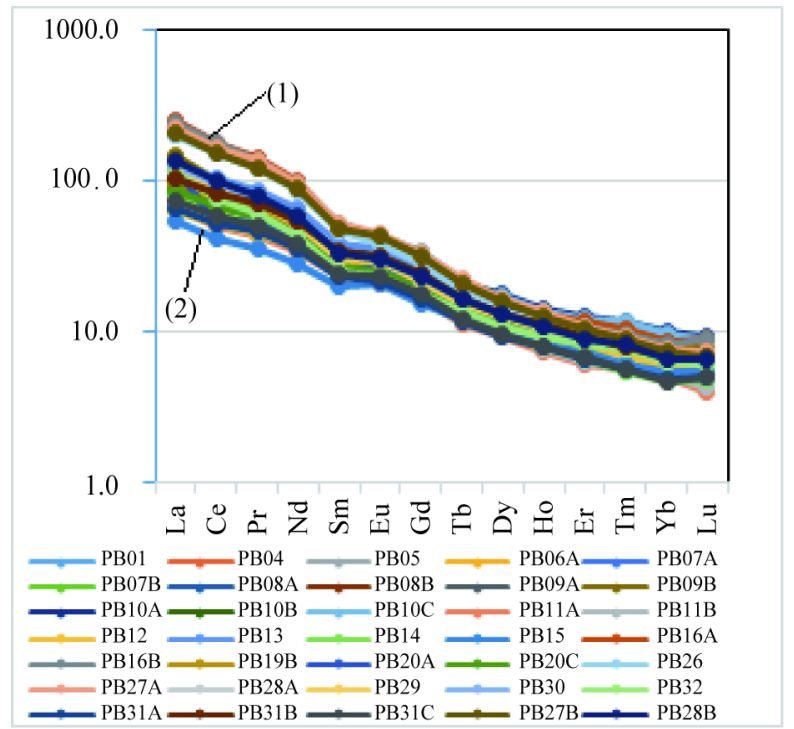

(e)

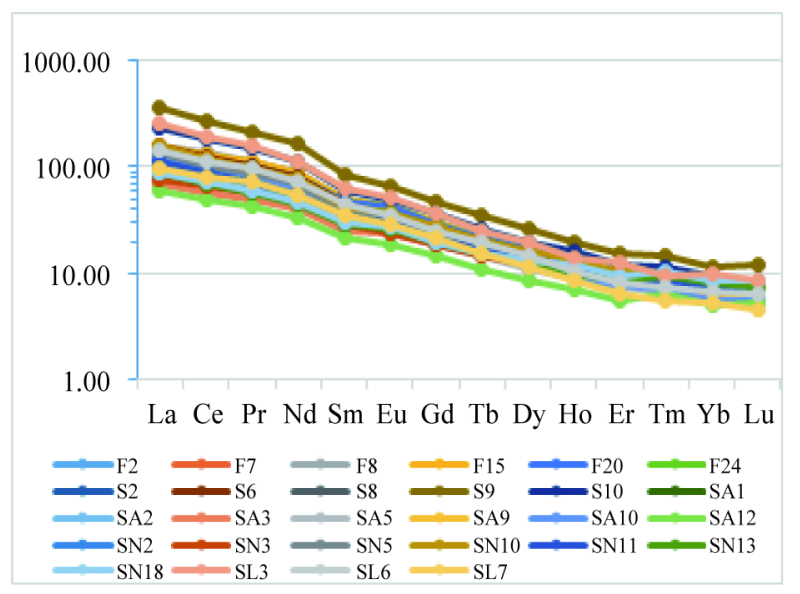

(g)

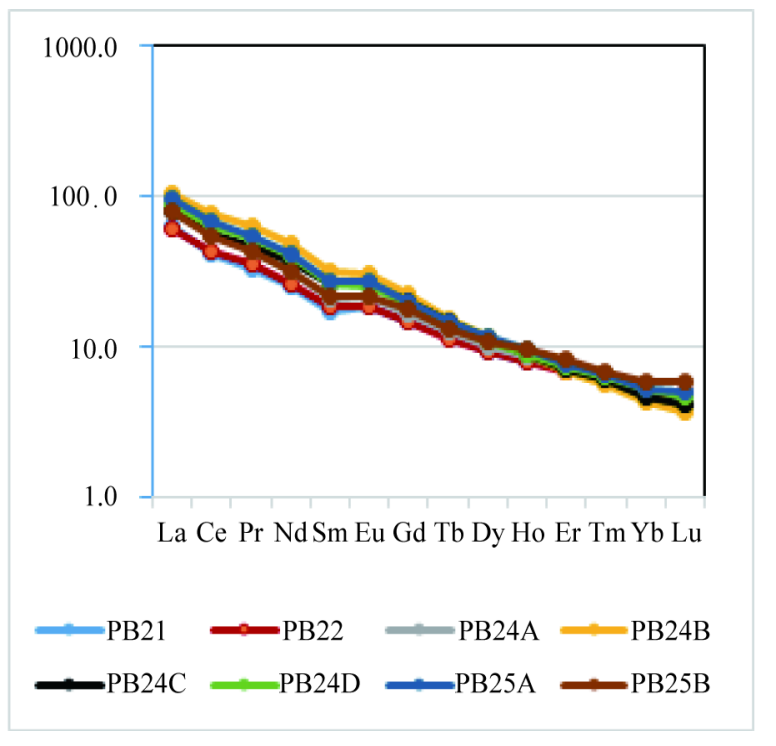

(f)

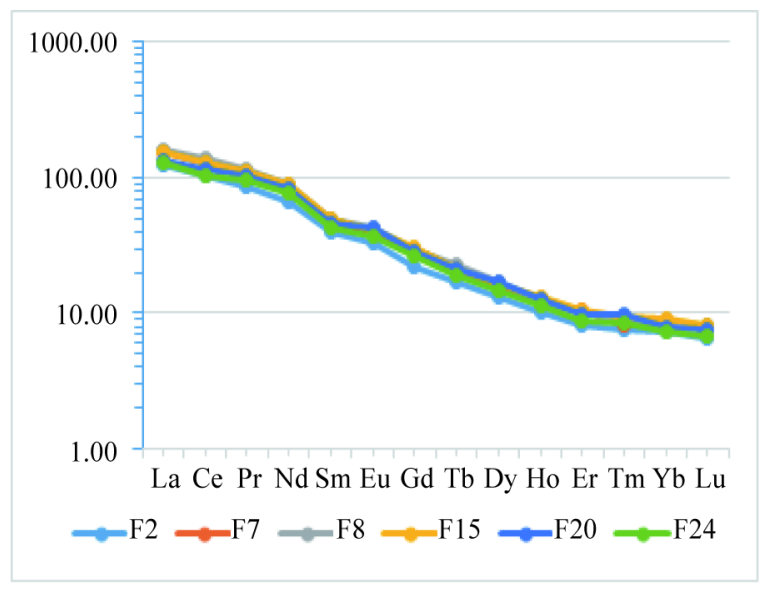

(h)

Figure 4. Chondrites C1 (Taylor and McLennan [17]) normalized REE patterns of the Tertiary (e) and Quaternary (f) lavas of Western Senegal and those Tertiary (g) and Quaternary (h) of the Cape Verde Islands [Fogo F2 (2), F7 (7), F8 (8), F15 (15), F20 (20), F24 (24); Santiago S2 (2), S6 (6), S8 (8), S9 (9) and S10 (10); Sao Vicente SA1 (1), SA2 (2), SA3 (3), SA5 (5), SA9 (9) SA10 (10) and SA12 (12); Sao Nicolau SN2 (2), SN3 (3) SN5 (5), SN10 (10), SN11 (11), SN13 (13) and SN18 (18); Sal: SL3 (3), SL6 (6) and SL7 (7)] (Doucelance et al. [14]). 2, 7, 8, 9, 10, 11, 12, 13, 15, 20 and 24 are the numbers given by Doucelance et al. [14]. F2, F7, etc. is the new numbering that we have assigned to the samples of Doucelance. 
The basalt spectra of Western Senegal [Tertiary (e) and Quaternary (f)] and of the Cape Verde Islands [Tertiary (g) and Quaternary (h)] show a high enrichment in light rare earth elements (LREE) [60 to $150 \times$ chondrites] and a slight enrichment in heavy rare earth elements (HREE) [5 - $20 \times$ chondrites]. This feature reflects a high fractionation of the LREE compared with the HREE in Western Senegal's basalts $\left[\mathrm{La}_{\mathrm{N}} / \mathrm{Yb}_{\mathrm{N}}\right)$ Average = 17.86 (Tertiary lavas) and 17.95 (Quaternary lavas); $\left(\mathrm{La}_{N} / \mathrm{Sm}_{\mathrm{N}}\right.$ ) Average $=3.68$ (Tertiary lavas) and 3.70 (Quaternary lavas)]. The lavas of Western Senegal and those of the Cape Verde Islands $\left[\mathrm{La}_{N} / \mathrm{Yb}_{\mathrm{N}}\right.$ ) Average $=18.10$ (Tertiary lavas) and 17.38 (Quaternary lavas); $\left(\mathrm{La}_{N} / \mathrm{Sm}_{\mathrm{N}}\right)$ Average $=3.28$ (Tertiary lavas) and 3.13 (Quaternary lavas)] show slight variations in LREE/HREE ratio. Consequently, the basalts of Western Senegal show more similarities with the basalts of the oceanic islands. Positive anomalies to a lesser degree in Eu have been observed. They characterize the fractionation of the plagioclases. Two groups of Western Senegal's Tertiary lavas have been identified: the first group (1) which is richer in LREE, consists of the Tertiary samples PB01, PB04, PB05, PB11A, PB11B, PB16A, PB16B, PB27A and PB27B. The second group (2), which is less rich in LREE, consists of the remaining Tertiary samples. These groups are different from each other (Figure 5) in the co-variance diagrams La/Yb (i), La/Sm (j).

The spectra of rare earth elements average compositions (Figure 6) normalized by C1-chondrites (Taylor and McLennan, [17]) of the Tertiary and Quaternary lavas of Western Senegal compared to those of the Cape Verde Islands (DOUCELANCE [14]), and those of the alkaline basalts of Cameroon (Dongmo [18]) and Ethiopia (Treuil and Joron [19]), and those of the OIB (Sun and McDonough [15]) and the BHVO-2 reference of Kalauea, Hawaii (from GEOREM data base), show that the lavas of this volcanic provinces have very similar HREE levels expected the Quaternary lavas of Western Senegal. On the contrary, compositions in LREE differ rmarkedly; they are closer to those of the intraplate alkaline basalts of Cameroon and OIB (Sun and McDonough [15]). As for the Quaternary ones of Western Senegal they have lower levels of rare earths elements than the Tertiary ones of Western Senegal, of the Cape Verde Islands, of Cameroon, and the OIB, and are closer to the BHVO-2 reference.

\section{Study of the Differentiation and Petrogenesis}

\subsection{Variation of the Major Elements}

The behaviour of the major elements with regard to the differentiation index variation reveals a geochemical continuum that suggests a high probability of co-geneticism between the Tertiary and Quaternary lavas of Western

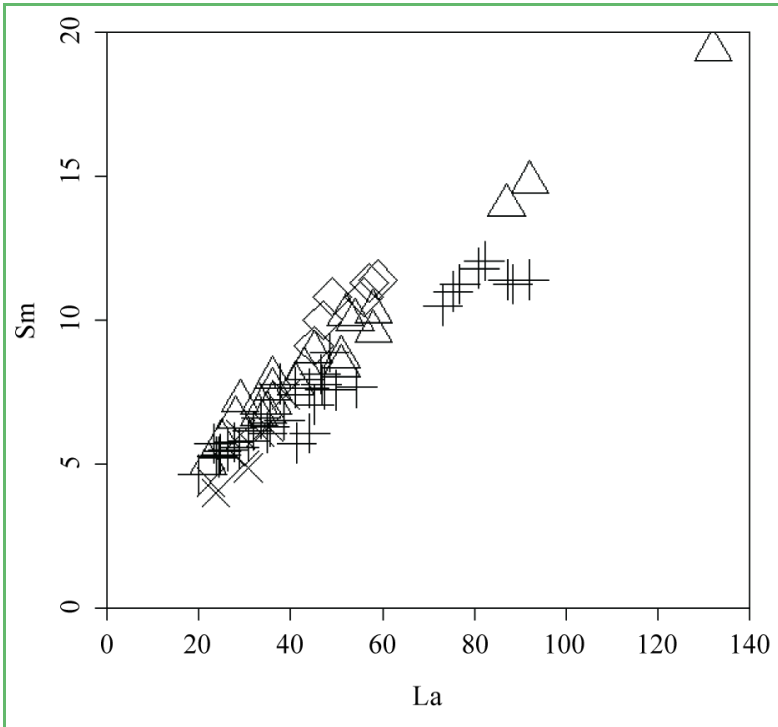

(i)

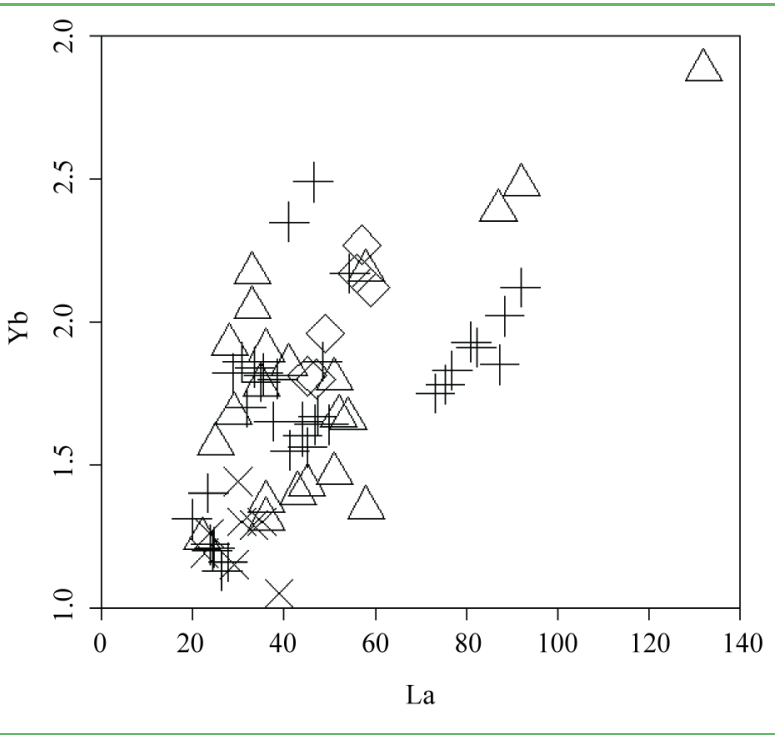

(j)

Figure 5. Diagram of co-variation La/Yb (i), La/Sm (j) Tertiary and Quaternary lavas of Western Senegal and Cape Verde Islands. +: Tertiary lavas of Western Senegal; ×: Quaternary lavas of Western Senegal tertiary; $\Delta$ : Quaternary lava Cape Verde islands; $\diamond$ : Teriary lava of the Cape Verde Islands. 


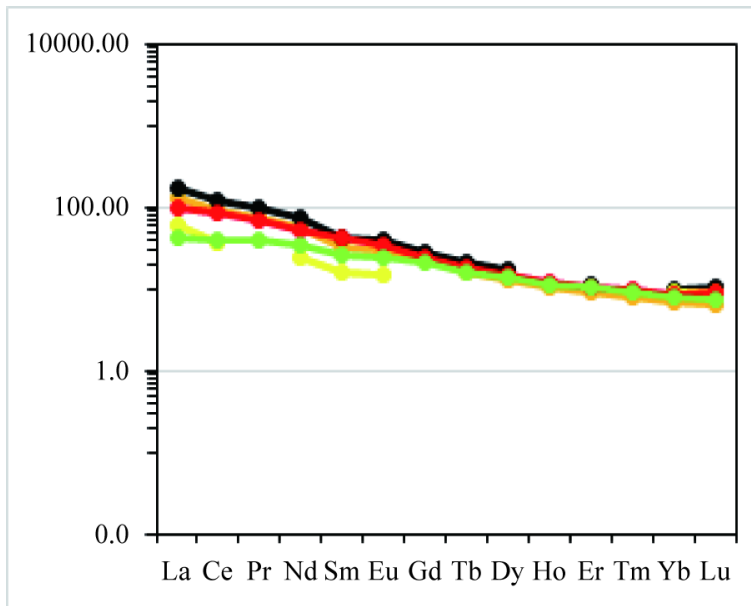

(k)

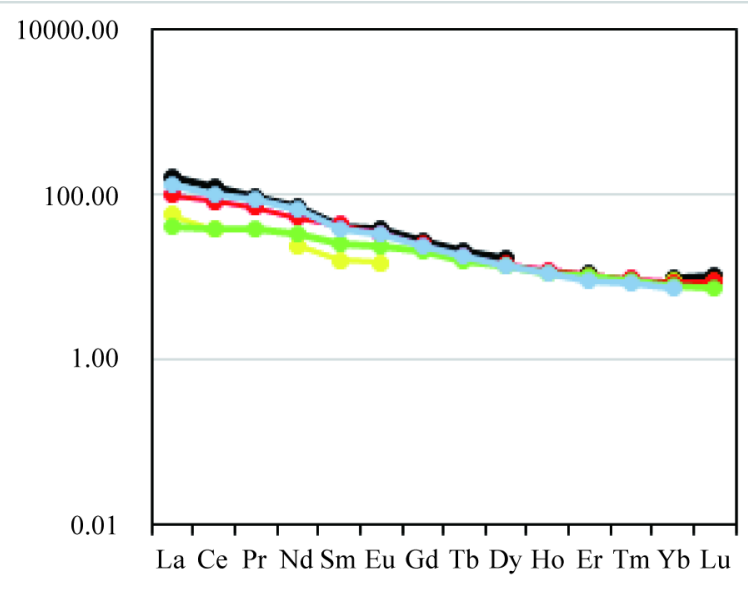

(m)

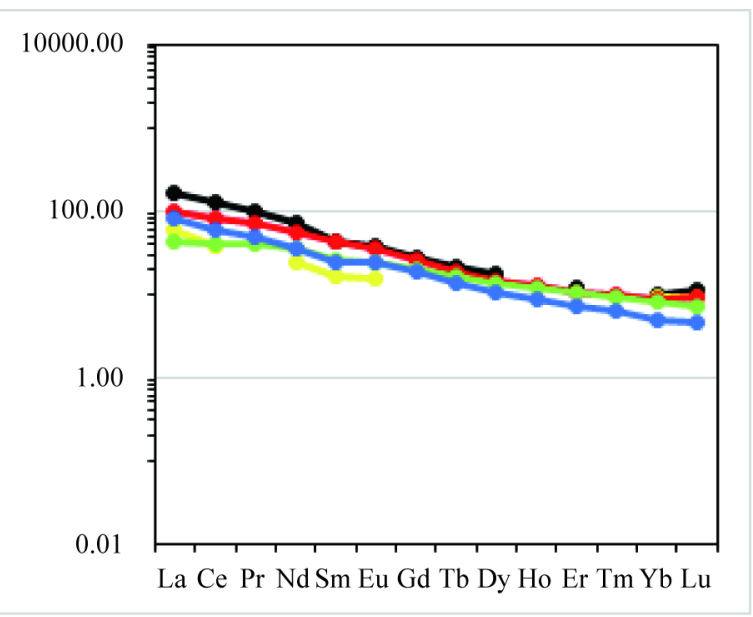

(l)

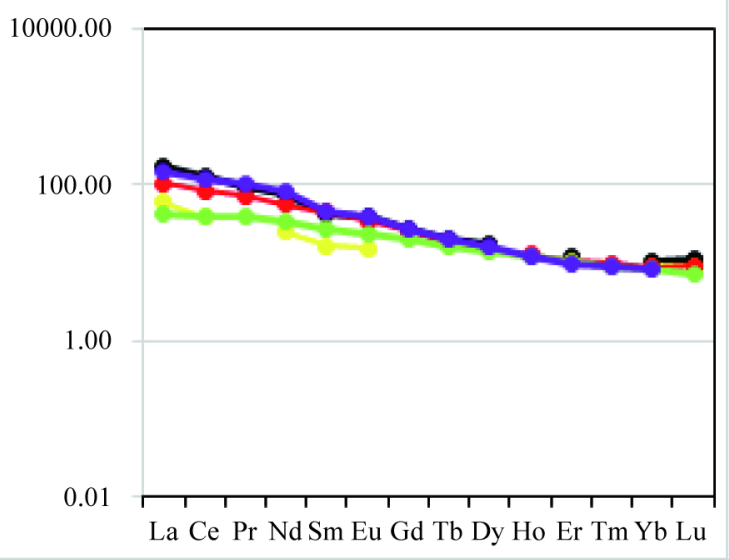

(n)

Figure 6. Spectra of average C1-chondrite (Taylor and McLennan, [17]) normalized abundance patterns of REE in average of the Tertiary ((k) orange) and Quaternary ((l) dark blue) lavas of western Senegal and those Tertiary ((m) purple) and Quaternary ((n) light blue) of the Cape Verde islands (Doucelance [14]) compared with those of the alkaline basalts of Cameroon (black; Dongmo [18]) and Ethiopian rift (yellow; Treuil and Joron [19], the OIB (red; Sun and McDonough [16]) and the BHVO-2 référence, Kalauea, Hawaii (green) [from GEOREM data base at http://georem.mpch-mainz.gwdg.de].

Senegal. $\mathrm{MgO}, \mathrm{CaO}, \mathrm{TiO}_{2}, \mathrm{P}_{2} \mathrm{O}_{5}$ and $\mathrm{Fe}_{2} \mathrm{O}_{3}$ have negative correlations with $\mathrm{SiO}_{2}$ (figure not included) and positive correlations with the $\mathrm{Mg} \#$ (Figure 7). The $\mathrm{Na}_{2} \mathrm{O}, \mathrm{K}_{2} \mathrm{O}$ and $\mathrm{Al}_{2} \mathrm{O}_{3}$ show positive correlations with $\mathrm{SiO}_{2}$ and negative correlations with Mg\# (Figure 7). The decreasing contents in $\mathrm{MgO}, \mathrm{CaO}, \mathrm{TiO}_{2}, \mathrm{Fe}_{2} \mathrm{O}_{3}$ and $\mathrm{P}_{2} \mathrm{O}_{5}$ could be related to the separation of olivines, pyroxenes, and plagioclase from the titanomagnetite and from the ilmenite through fractional crystallization. The successive appearance of these minerals led, during the magma evolution, to the modification into basanites, alkali olivine basalts and nephelinites of the chemistry of these basalts.

\subsection{Variation of Trace Elements}

The average Nb, Zr, Th, Ta contents of the Tertiary basalts of Western Senegal (Table 5) are higher than the contents of the oceanic island basalts (Sun and McDonough, [16]). The Nb, Zr, Th, Ta contents of Western Senegal's Quaternary basalts show levels that are very similar to those mentioned above. The variations of the Ni and Co contents of Western Senegal's basalts reveal that they have more similarities with the less evolved magmas. In the Cape Verde Islands, the Ni contents of the Quaternary basalts (Fogo) range from 34 to $113 \mathrm{ppm}$ while the Ni contents of the Tertiary basalts range from 34 to 313 ppm (Santiago), 205 - 553 ppm (Sao Vincete), 163 - 349 ppm (Sao Nicolau), 232 - 611 ppm (Sal) (Doucelance et al., [14]). 

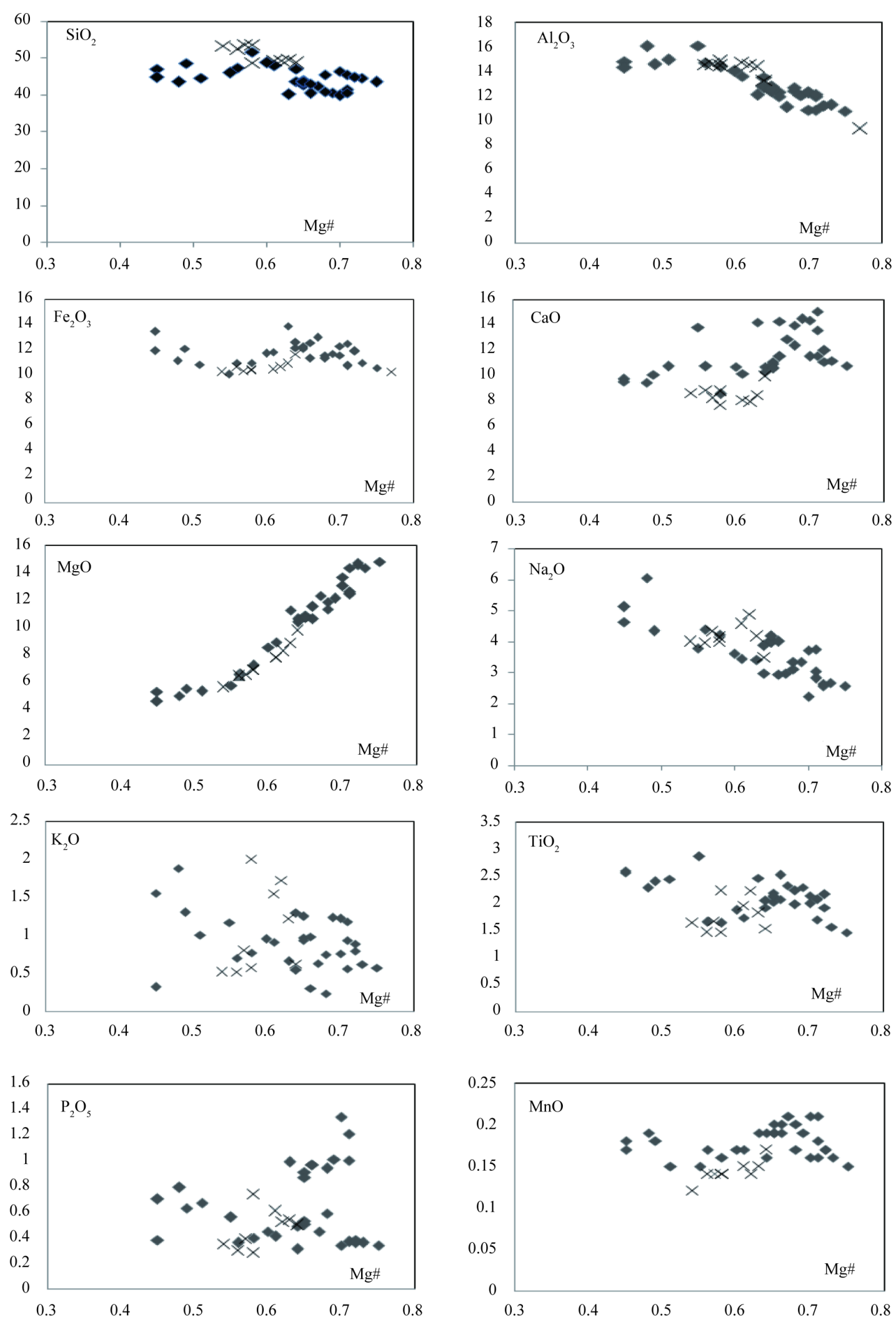

Figure 7. Variations of major components versus Mg\# in the Tertiary and Quaternary lavas of Western Senegal (Cape Verde Peninsula and the Thiès Plateau). 
The trace elements of the Tertiary and Quaternary basalts of Western Senegal and the Cape Verde Islands normalised to C1 chondrites (Taylor and McLennan, [17]), are shown in Figure 8.

The spectra of the Tertiary lavas which are subparallel to the spectra of the Quaternary volcanic rocks of Western Senegal suggest that they are co-genetic in nature. The basalts of the Cape Verde Islands also have spectra that are subparallel to the spectra of Western Senegal (Tertiary and Quaternary), which also bear evidence of their possible co-genetic character. The $\mathrm{K}, \mathrm{Rb}$, and $\mathrm{Pb}$ negative anomalies and the $\mathrm{Eu}$ (weak), $\mathrm{Nb}, \mathrm{Sr}$ and Ta positive anomalies observed here are typical of the basalts of the oceanic islands. Similar anomalies of the same elements have been described in the islands of Sao Nicolau and Santiago (Millet, [20]). In addition, the C1 chondrite-normalized data collected by Doucelance et al., [14] from the different islands of Cape Verde also show $\mathrm{K}$ and $\mathrm{Rb}$ negative anomalies and $\mathrm{Nb}$, La, $\mathrm{Sr}$ and Ta positive anomalies [Figure 8(q) and Figure 8(r)]. The $\mathrm{K}$ anomalie are due to the fractionation of the plagioclase.

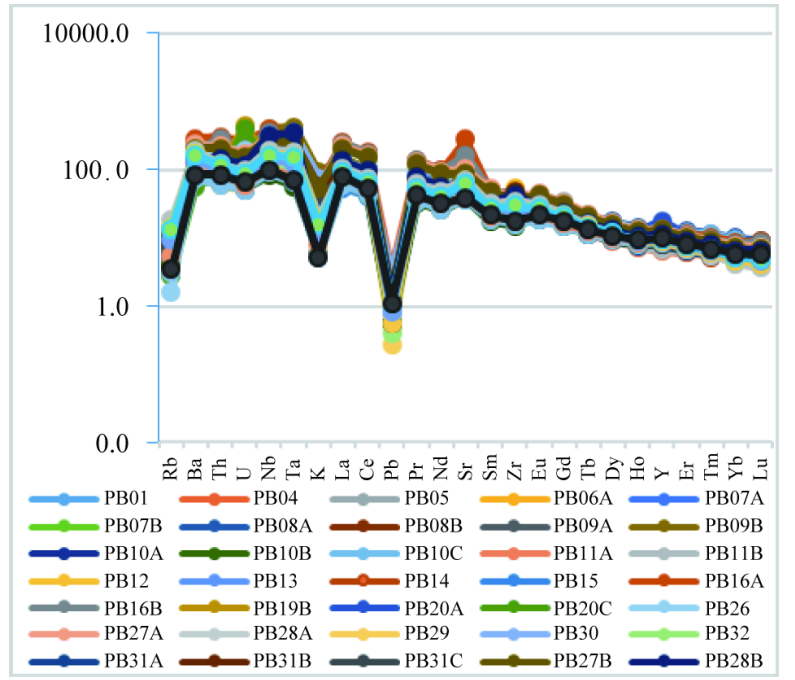

(o)

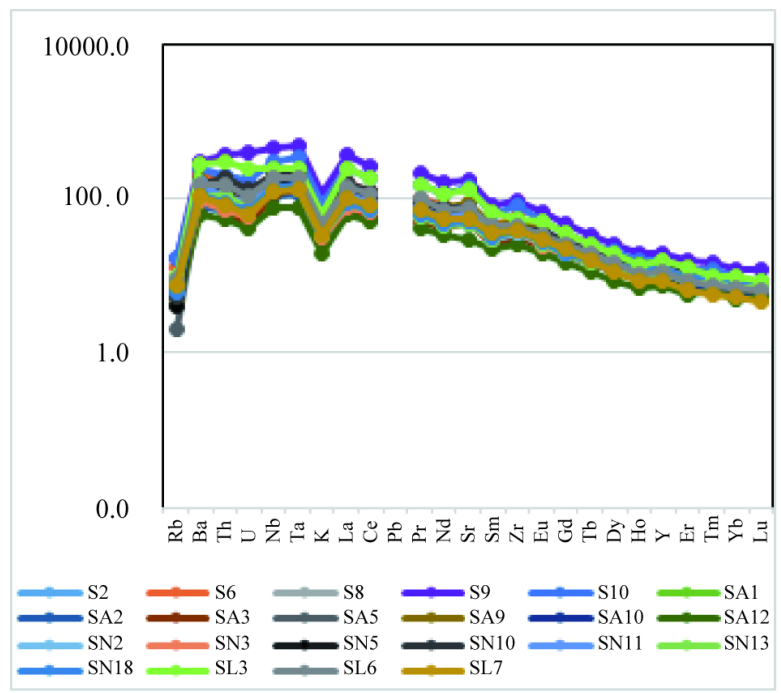

(q)

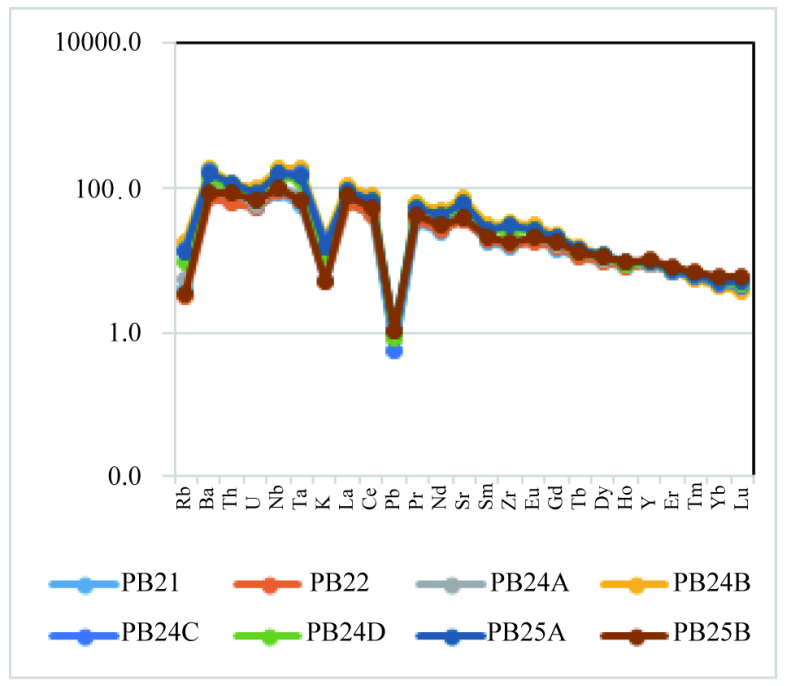

(p)

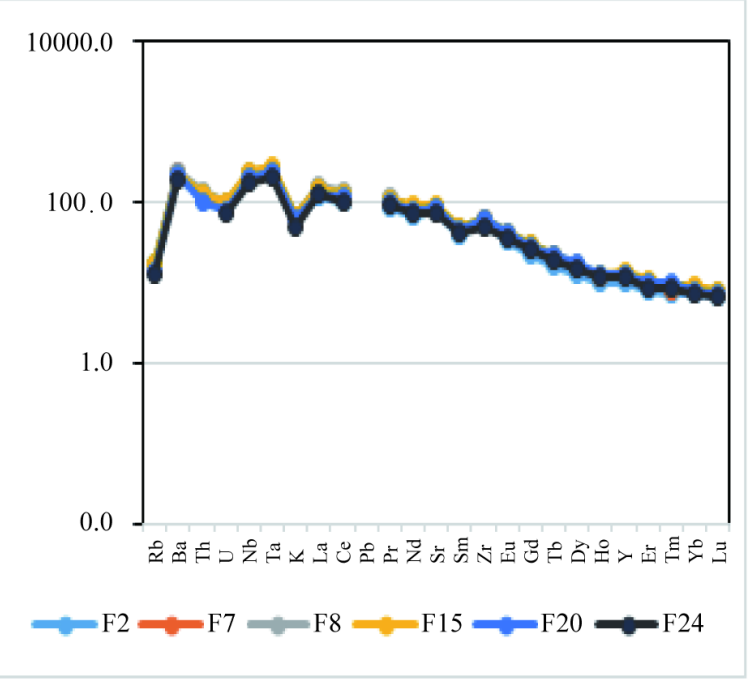

(r)

Figure 8. Chondrites C1 (Taylor and McLennan, [17])-normalized patterns of the trace elements abundance of the Tertiary (o) and Quaternary (p) lavas of Western Senegal and those Tertiary (q) and Quaternary (r) of the Cape Verde Islands) [Fogo F2 (2), F7 (7), F8 (8), F15 (15), F20 (20), F24 (24); Santiago S2 (2), S6 (6), S8 (8), S9 (9) and S10 (10); Sao Vicente SA1 (1), SA2 (2), SA3 (3), SA5 (5), SA9 (9) SA10 (10) and SA12 (12); Sao Nicolau SN2 (2), SN3 (3) SN5 (5), SN10 (10), SN11 (11), SN13 (13) and SN18 (18); Sal: SL3 (3), SL6 (6) and SL7 (7)] [Doucelance et al. [14]]. 2, 7, 8, 1520 and 24 are the numbers given by Doucelance et al. [14]. F2, F7, etc. is the new numbering that we have attributed to these samples to avoid the repetition of the numbers in the differents islands of Cape Verde. 
The broadened spectra of compositions of trace elements in the alkaline basalts of Western Senegal compared to those of the Cape Verde Islands (DOUCELANCE [14]), the intra plate alkaline basalts of the Cameroon (Dongmo [18]), the Ethiopian rift (Joron winch and [20]), to those of the OIB (Sun and McDonough [16]) and the BHVO-2 reference standard (Menard [21]), show that they are all similar and have positive Ba, Th, U, Sr, Zr anomalities, and strong negative $\mathrm{Ta}, \mathrm{Rb}, \mathrm{K}, \mathrm{Pb}$ anomalities. However, enrichment in the more incompatible elements is highly variable from one zone to another. The BHVO-2 benchmark is less enriched in $\mathrm{Ba}, \mathrm{Th}, \mathrm{U}, \mathrm{Nb}$ and Ta than the alkaline basalts of theafore mentioned volcanic provinces.

The Tertiary lava Nb/Th and Nb/Ta ratios $(15.7 ; 15.1)$ of Western Senegal bring them closer to the basalts of the Hawaii Archipelago $(\mathrm{Nb} / \mathrm{Th}>15 ; \mathrm{Nb} / \mathrm{Ta}=15.8)$ [50 \pm 14 ; Sims and De Paolo [22] and Mevel. [23]. On the contrary, those of the Quaternary lavas (12.8) bring them closer to those of Ruturu Islands, Mangaia, Tubuai (12 - 15) which are HIMU type OIBs (Graham [24]; Mevel [23]).

\subsection{Petrogenesis}

The study of the fractionation process and the analysis of the behavior of the major elements with regard to the Mg\# and to some trace elements show that the major geochemical property of Western Senegal's volcanism is controlled by the fractional crystallization of the olivine, pyroxene and plagioclase. The olivine, pyroxene and plagioclase as well as the opaque minerals constitute the major mineral phases observed in the various lavas, with variable ratios from one facies to another. The basanites contain much more olivine and pyroxene than the alkali olivine basalts, which brings evidence of a differentiation through fractional crystallization. The Tertiary lavas are more undersaturated and undifferentiated than the Quaternary lavas. The Cape Verde lavas are more undersatured in slicia than those of the Western Senegal's lavas. This differentiation may have been caused by the existence of several lavas exiting points for the same magma, with conditions of formation and chemistry that are different from one area to another. The magmatic differentiation occurred through the fractionation of olivine and pyroxene as evidenced by the gradual decrease of the calcium and the increase in silica and alumina in the less magnesian lavas (Quaternary lavas). This is illustrated by the shift in the diagrams (Mg\# versus major elements) of the Quaternary lava towards higher silica, alumina and sodium contents and towards lower iron, calcium, magnesium and titanium values for an identical Mg\# (Figure 5). This can be interpreted as being caused by the effect of one or more components with weak iron, calcium and magnesium contents and high silica, alumina and sodium contents during the rifting process of the Atlantic Ocean. The REE enrichment of the Western Senegal basalts is very close to that of the basalts of the oceanic islands because of the high LREE enrichment and slight HREE enrichment. The negative anomalies $(\mathrm{K}, \mathrm{Rb}$ and $\mathrm{Pb})$ and positive anomalies $(\mathrm{Nb}$, $\mathrm{Ta}, \mathrm{Sr}$, and $\mathrm{Eu}$ ) observed in the trace elements patterns bring them closer to the basalts of the oceanic islands. The average levels of silica in the Tertiary basalts of Western Senegal are comparable to the basalt contents of Fogo, Sao Vicente, Sao Nicolau, Sal islands $\left(\mathrm{SiO}_{2}<45 \%\right)$ (Doucelance et al., [14]). The MgO average contents of the Tertiary lavas are located in-between the contents of the southern islands (7.97\%) [Fogo, Santiago] and those of the northern islands (13.14\%) (Doucelance et al. [14]). The Quaternary basalts of Western Senegal are more differentiated than all the basalts of the Cape Verde Islands although their MgO contents remain comparable. Like Western Senegal's basalts, the basalts of the Cape Verde islands show more similarities with the less evolved magmas. These are related to the fractionation of the olivine and clinopyroxene. The $\mathrm{Ni}$ and $\mathrm{Cr}$ contents are included in these minerals. The Ni and Cr contents of the Tertiary and Quaternary basalts of Western Senegal, and those of Santiago, Fogo, Sao Vicente, Sao Nicolau and Sal islands, show similarities with rocks originating from primary magmas. The different features listed above show a possible genetic link between the basalts of Western Senegal and the basalts of the Cape Verde Archipelago. The latter are generated from a lower-mantle-type source (Millet, [20]). The distribution of $\mathrm{K}_{2} \mathrm{O}$ based on the number of samples from the lavas of Western Senegal and the Cape Verde islands is shown in Table 6.

The Tertiary and Quaternary basalts of Western Senegal range from medium to high concentrations of potassium as well as the Tertiary basalts of the Cape Verde Islands. The Quaternary basalts of the Cape Verde Islands show only high potassic contents.

\section{Geodynamic Context of the Formations}

In order to determine the geotectonic context of the volcanism in Western Senegal, we used the geotectonic diagrams of Mullen [25] and Meschede [26] (Figure 9). These geochemical patterns were obtained using the 
Table 6. Distribution of $\mathrm{K}_{2} \mathrm{O}$ based on the number of samples in the lavas of the Western Senegal and those of the Cape Verde Islands.

\begin{tabular}{cccccc}
\hline & \multicolumn{3}{c}{ Werstern Senegal } & \multicolumn{2}{c}{ Islands Cape Verde } \\
\cline { 2 - 6 } & \multicolumn{2}{c}{ Tertiary } & Quaternary & Quaternary & Tertiary \\
\hline $\mathbf{K}_{\mathbf{2}} \mathbf{O}$ & $\begin{array}{c}\text { Number of samples } \\
\text { (Cape Verde Peninsula) }\end{array}$ & $\begin{array}{c}\text { Number of samples } \\
\text { (Thiès Plateau) }\end{array}$ & $\begin{array}{c}\text { Number of samples } \\
\text { (Cape Verde Peninsula) }\end{array}$ & $\begin{array}{c}\text { Number of samples Fogo } \\
\text { (active volcano) }\end{array}$ & Number of samples \\
$\mathbf{0 - 0 . 2}$ & 0 & 0 & 0 & 0 & 0 \\
$\mathbf{0 . 2}-\mathbf{0 . 8}$ & 14 & 1 & 4 & 0 & 6 \\
$\mathbf{0 . 8}-\mathbf{3}$ & 11 & 8 & 4 & 6 & 16 \\
\hline
\end{tabular}

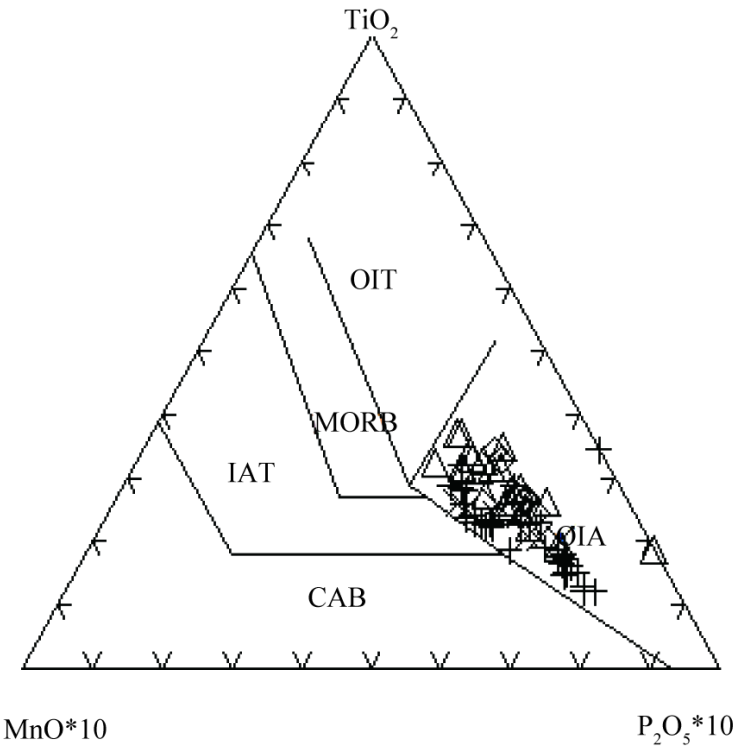

(k)

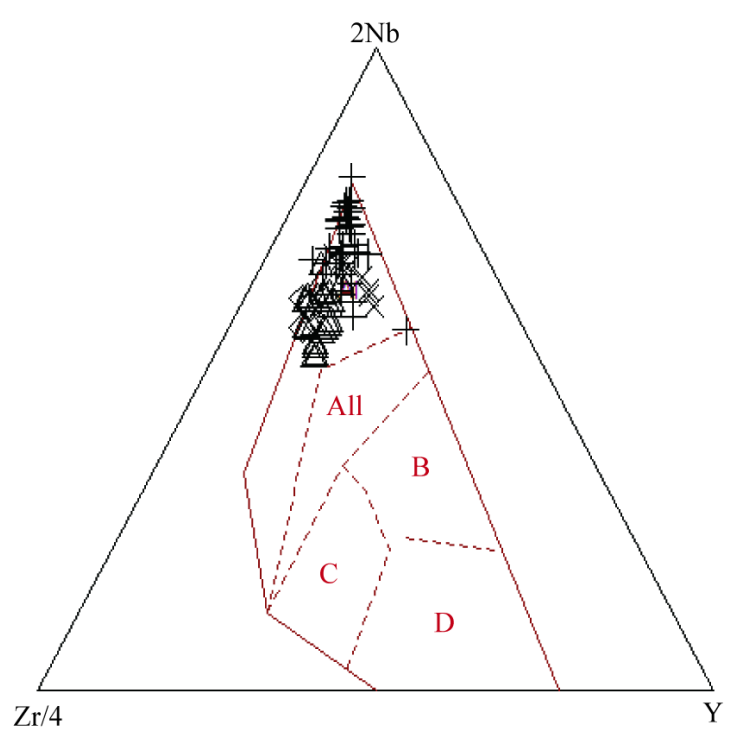

(l)

Figure 9. Distribution of the lavas in Western Senegal and the Cape Verde Islands in the diagrams (k) of Mullen [25] and (l) of Meschede [26]. OIAB: ocean island alkali basalt; OIT: ocean island tholeiite; IAT: island-arc tholeiite; CAB: calc-alkaline basalt; MORB: mid-ocean ridge basalt; AI-AII = within plate alkaline basalts; AII-C: within plate tholeiites; B-D = midocean ridge basalts; C-D = basalts of island arc; +: Tertiary lavas of Western Senegal; $\times$ : Quaternary lavas of Western Senegal; $\Delta$ : Tertiary lavas of the Cape Verde Islands; $\diamond$ : Tertiary lavas of the Cape Verde Islands.

MINPET 2.02 software.

The position of the various basalt samples of Western Senegal and the Cape Verde Islands (Figure 9) in Mullen's [25] and Meschede's [26] geotectonic diagrams shows that the volcanism of Western Senegal and Cape Verde Islands belongs to the ocean island alkali basalt.

\section{Conclusions}

The present work was devoted to determine the petrogenesis of Western Senegal's basalts and the type of volcanisme involved from the recent geochemical data. The analysis indicated that the geochemistry of the Tertiary and Quaternary basalts of Western Senegal followed a progressive geochemical differentiation despite the discontinuity in time of the volcanism. The variations observed in these rocks may be viewed as the result of different possible compositions of the source materials of these basalts, but also as the effect of interactions between primitive magmas and the various chambers that have been crossed during the ascent to the surface. In this context, we may envisage a possible plume-lithosphere interaction, together with assimilation and crystallization phenomena, in addition to post-eruptive interaction with sea water. The petrographic and geochemical data of the Tertiary and Quaternary lavas of Western Senegal reveal two types of undifferentiated lavas that 
produced olivine basanites, alkali olivine basalts and nephelinites (Tertiary lavas). There are two groups of the Tertiary lavas. The first group, less differentiated, is represented by the Tertiary lavas of the Cape Verde Peninsula and the second group, more differentiated, is represented by the lavas of the Thiès Plateau.

The analysis of the data as referred to the age of the different Tertiary and Quaternary samples shows no evolutionary relationships with them (Table 1 and Table 2).

The main geochemical data collected from the Cape Verde Peninsula and the Thiès Plateau were compared to the data collected from the Cape Verde Islands. The basalts of Western Senegal, as well as the basalts of the Cape Verde Islands, are similar to the basalts from a slightly evolved magma. The high LREE and slight HREE enrichments in Western Senegal's basalts, show similarities with the basalts of the oceanic islands. The positive anomalies $(\mathrm{Nb}, \mathrm{Ta}$ and $\mathrm{Eu})$ and negative anomalies $(\mathrm{K}, \mathrm{Pb}, \mathrm{Rb})$ are also characteristic of the OIB. This reveals that the volcanism of Senegal belongs to the hot spot type. The geochemical and geotectonic data collected in this study on Western Senegal's basalts reveal a volcanism that is similar to that of the Cape Verde Islands. The $\mathrm{K} / \mathrm{Ar}$ ages available upon the volcanic rocks of Western Senegal and the Cape Verde Islands (see Table 2) indicate that these two volcanic activities seem to have occurred simultaneously. In the Cape Verde Islands, the first under water volcanic activity which is around 45 million years old (Duyck [27]) gives carbonatites and alkaline basalts. In Western Senegal, this event can be correlated to the ages deducted by Sarr et al. (2000) [48 - 45 MYs]. The second volcanic event occurred between 26 - 22 to 3 MYs and gave alkaline basalts, slag, diabase, and syenite (Mitchell et al., [28]; Gerlach et al. [29]; Torres [30]; Jorgensen and Holm [31]; Torres et al., [32]; Holm et al., [33]; Duprat et al., [34]; Holm et al., [35]; Dyhr and Holm, [36]; Madeira et al., [37]). In Western Senegal, this volcanic even occurred between $35 \pm 1.5$ and $5.3 \pm 0.3$ MYs (Crévola et al., [6]). The similarities observed from the ages and lithologies of those magmatic events establish closer links between the volcanism of Western Senegal and that of the Cape Verde Islands.

The results were discussed and compared with the two alkaline provinces of the Cameroon and Ethiopian rift. The volcanic activities of the peninsula of Cape Verde and Cape Verde Islands have patterns similar to those of the CameroonVolcanic Line and the Ethiopian Rift (Figure 10). Volcanic products are set up in an oceanic (Cape Verde Islands), or continental (western Senegal) lithospheric plate probably related to the activity of a hot spot. Seismic tomography studies carried out by Montelli et al. [38] reveal the existence of a deep hot spot, vertical to the Cape Verde Islands. In Western Senegal no hot spot has been reported by previous studies. The significant magmatic activity from the Tertiary to the Quaternary almost simultaneously affects the Cape Verde

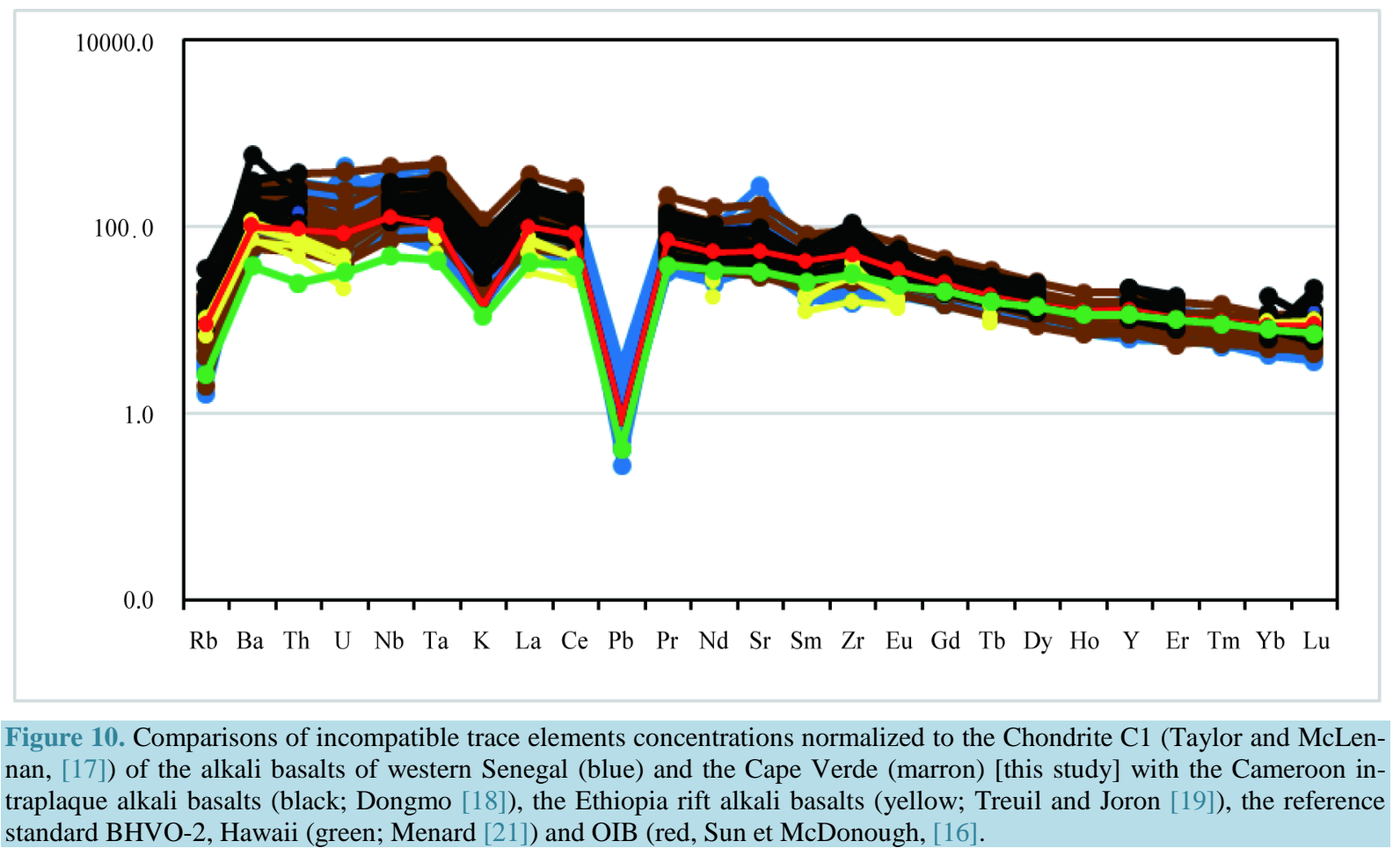


Islands and Western Senegal and might suggest the existence of a drift eastwards of the magmatism related to the hot spot of the Cape Verde Islands. This could possibly be facilitated by the sub-continental lithospheric delamination of West Africa following an eastward expansion of the pen located directly above the volcanic edifices of the Cape Verde Islands.

\section{Acknowledgements}

We thank Alejandro Munilla and the members of the scientific team of the ALS Laboratory Group, Minerals Division and Geochemistry in Seville (Spain) for carrying out our major elements, trace and rare earth elements samples analyzes.

\section{References}

[1] Dia, A. (1982) Contribution à l'étude des caractéristiques pétrographiques, pétrochimiques et géochimiques des granulats basaltiques de la presqu'île du Cap-Vert et du plateau de Thiès. Thèse $3^{\mathrm{e}}$ cycle, University of Dakar, Dakar, $183 \mathrm{p}$.

[2] Lo, G. (1988) Le volcanisme quaternaire de Dakar (Sénégal Occidental): Particularités pétrographiques, caractères géochimiques, implications pétrogénétiques. Thèse 3 è cycle, Nancy-Université, Lorraine, 202 p.

[3] Lo, P.G., Dia, A. and Kampunyu, A.B. (1992) Cenozoic Volcanism in Western Senegal and Its Relationship to the Opening of the Central Atlantic Ocean. Tectonophysics, 209, 281-291. http://dx.doi.org/10.1016/0040-1951(92)90035-5

[4] Lompo, M. (1987) Méthodes et étude de la fracturation et des filons; exemple de la région du Cap-Vert (Sénégal). Mém. D.E.A. Fac. Sci. Dakar., 59 p, 16 fig., 2 ann.

[5] Mellet, O. (1993) Pétrologie du magmatisme volcanique quaternaire de la presqu'île du Cap-Vert. Mém. D.E.A.Géosciences. Fac. Sci. Dakar.

[6] Crevola, G., Cantagrl, J.M. and Moreau, C. (1994) Le volcanisme cénozoïque de la Presqu’île du Cap-Vert (Sénégal): Cadre chronologique et géodynamique. Bulletin de la Société géologique de France, 5, 437-446.

[7] Templeton, R.S.M. (1971) The Geology of the Continental Margin between Dakar and Çape Palmas. Ln: Delany, F.M., Ed., The Geology of the East Atlantic continental Margin, Africa inst. Géol. Sci. Rep. No 70/16, 43-60.

[8] Bongrand, M.O. and Elouard, P. (1968) Nature pétrographique de la formation de l’Hôpital de Dakar. Ann. Fac. Sc., Dakar, 22 sér. Sc. Terre, No 2, p. 5-32, 3 tabl., 3pl., 2 Annexes.

[9] Cantagrel, J.M., Jamond, C. and Lassere, M. (1978) Le magmatisme alcalin de ligne du Cameroun au Tertiaire inférieur: Données géochronologiques K/Ar. Compte Rendu Sommaire des Séances de la Société Géologique de France, 6 , 300-303.

[10] Sarr, R., Ndiaye, P.M., Niang-Diop, I. and Gueye, M. (2000) Datation par les foraminifères planctoniques d'une activité volcanique, d’âge lutétien, à Toubab Dialaw (Sénégal Occidental). Bulletin de la Société Géologique de France, 171, 197-205. http://dx.doi.org/10.2113/171.2.197

[11] Elouard, P. and Hebrard, L. (1976) Notice explicative de la carte géologique de la tête de la presqu'île du Cap-Vert au 1/20000 (Sangalkam). Bull. Dir. Mines et Géol. (Sénégal), 33 p.

[12] Mpassi, R.D. (2004) Contribution à l'étude tectonique de la partie occidentale du bassin sénégalo-mauritanien. Thèse $3^{\mathrm{è}}$ cycle, Univ. Cheikh Anta Diop Dakar (Sénégal). 344 p.

[13] Bellion, Y. and Cevola, G. (1991) Cretaceous and Cenozoic Magmatism of the Senegal Basin (West Africa): A Review. In: Kampuzu, A.B. and Lubala, R.T., Eds., Magmatism in Extensional Settings: The Phanerozoic Africa Plate, Springer Verla Publ., Berlin, 189-208. http://dx.doi.org/10.1007/978-3-642-73966-8 8

[14] Doucelance, R., Escrig, S., Moreira, M., Gariepy, C. and Kurz, M.D. (2003) Pb-Sr-He Isotope and Trace Element Geochemistry of the Cape Verde Archipelago. Geochimica et Cosmochimica Acta, 67, 733.

[15] Irvine, I.N. and Baragar, W.R.A. (1971) A Guide to Chemical Classification of the Common Volcanic Rocks. Canadian Journal of Earth Sciences, 8, 523-548. http://dx.doi.org/10.1139/e71-055

[16] Sun, S.S. and McDonough, W.F. (1989) Chemical and Isotopic Systematics of Oceanic Basalts: Implications for Mantle Composition and Processes. In: Saunders, A.D. and Norry, M.J., Eds., Magmatism in the Ocean Basins, Geological Society Special Publication, London, 313-345. http://dx.doi.org/10.1144/gsl.sp.1989.042.01.19

[17] Taylor, S.R. and McLennan, S.M. (1985) Continental Crust; Its Compositions and Evolution. 312. Backwell Scientific Publications, Oxford.

[18] Dongmo, A.K., Wandi, P., Pouclet, A., Vicat, J.-P., Cheilletz, A., Nkouathio, D.G., Alexandrov, P. and Tchoua, F.M. (2006) Évolution volcanologique du mont Manengouba (Ligne du Cameroun); nouvelles données pétrographiques, 
géochimiques et géochronologiques.

[19] Treuil, M. and Louis, J.J. (1977) Utilisation des éléments hygromagmatophiles pour la simplification de la modélisation quantitative des processus magmatiques. Exemples de l’Afar et de la dorsale médio-atlantique.

[20] Millet, M.A. (2007) Interactions de Faibles Profondeurs et Géochimie des basaltes d'îles océaniques: implications sur les modes d'acquisition de la signature isotopique et sur la topologie mantellique. Thèse, Univ Blaise Pascal, UFR Sciences et Technologies, $224 \mathrm{p}$.

[21] Menard, G. (2014) Comportement des éléments traces au cours des processus de dégazage. Etude des volcans Piton de la Fournaise (Réunion) et Lascar (Chili).

[22] Sims, K.W.W. and Depaolo, D.J. (1997) Inferences about Mantle Magma Sources from Incompatible Element Concentration Ratios in Oceanic Basalts. Geochimica et Cosmochimica Acta, 61, 765-784. http://dx.doi.org/10.1016/S0016-7037(96)00372-9

[23] MEVEL (2003) Magmatisme des dorsales: Approches pétrologiques et géochimique. mevel@ipgp.fr

[24] Graham, D.W. (1987) Helium and Lead Isotope Geochemistry of Oceanic Volcanic Rocks from the East Pacific and South Atlantic. PhD Thesis, MIT/Woods Hole Oceanographic Institution. http://dx.doi.org/10.1575/1912/3948

[25] Mullen, E.D. (1983) $\mathrm{MnO} / \mathrm{TiO}_{2} / \mathrm{P}_{2} \mathrm{O}_{5}$ : A Minor Element Discriminant for Basaltic Rocks of Oceanic Environments and Its Implications for Petrogenesis. Earth and Planetary Science Letters, 62, 53-62. http://dx.doi.org/10.1016/0012-821X(83)90070-5

[26] Meschede, M. (1986) A Method of Discriminating between Different Types of Mid-Ocean Ridge Basalts and Continental Tholeiites with the Nb-Zr-Y Diagram. Chemica, 56, 207-218.

[27] DUYCK (2008) Archipel des îles du Cap-Vert: Histoire géologique.

[28] Mitchell, J.G., Le Bas, M.J., Zielonka, J. and Furnes, H. (1983) On Dating the Magmatism of Maio, Cape Verde Islands. Earth and Planetary Science Letters, 64, 61-76. http://dx.doi.org/10.1016/0012-821X(83)90053-5

[29] Gerlach, D.C., Cliff, C.A., Davies, G.R., Norry, M.J. and Hodgson, N. (1988) Magma Sources of the Cape Verdes Archipelago: Isotopic and Trace Element Constraints. Geochimica et Cosmochimica Acta, 52, 2979-2992. http://dx.doi.org/10.1016/0016-7037(88)90162-7

[30] Torres, P.C. (1998) Geologia e petrogénese das formações vulcânicas da ilha do Sal, Arquipélago de Cabo Verde. Dissertação apresentada ao Instituto de Investigação Científica e Tropical para prestação de provas d’acesso à categoria d’Investigador auxiliar, $212 \mathrm{p}$.

[31] Jǿrgensen, J.Ø. and Holm, P.M. (2002) Temporal Variation and Carbonatite Contamination in Primitive Ocean Island Volcanics from Sao Vicente, Cape Verde Islands. Chemical Geology, 192, 249-267. http://dx.doi.org/10.1016/S0009-2541(02)00198-5

[32] Torres, P.C., Silva, L.C., Serralheiro, A., Tassinari, C. and Munha, J. (2002) Enquadramento geochronologico pelo metodo K-Ar das principais sequencias volcano-estratigraficas da Ilha do Sal-Cabo Verde. Garcia de Orta, Série de Geologia, 18, 9-13.

[33] Holm, P.M., Grandvuinet, T., Friis, J., Wilson, J.R., Barker, A.K. and Plesner, S. (2008) An ${ }^{40} \mathrm{Ar}-{ }^{39} \mathrm{Ar}$ Study of the Cape Verde Hot Spot: Temporal Evolution in a Semistationary Plate Environment. Journal of Geophysical Research, 113, Article ID: B08201.

[34] Duprat, H.I., Friis, J., Holm, P.M., Grandvuinet, T. and Sǿrensen, R.V. (2007) The Volcanic and Geochemical Development of Sao Nicolau, Cape Verde Islands: Constraints from Field and ${ }^{40} \mathrm{Ar} /{ }^{39} \mathrm{Ar}$ Evidence. Journal of Volcanology and Geothermal Research, 162, 1-19. http://dx.doi.org/10.1016/j.jvolgeores.2007.01.001

[35] Holm, P.M., Wilson, J.R., Christensen, B.P., Hansen, S.L., Hein, K.M., Mortensen, A.K., Pedersen, R., Plesner, S. and Runge, M.K. (2006) Sampling the Cape Verde Mantle Plume: Evolution of Melt Compositions on Santo Antao, Cape Verde Islands. Journal of Petrology, 47, 145-189. http://dx.doi.org/10.1093/petrology/egi071

[36] Dyhr, C.T. and Holm, P.M. (2010) A Volcanological and Geochemical Investigation of Boa Vista, Cape Verde Islands; ${ }^{40} \mathrm{Ar} /{ }^{39} \mathrm{Ar}$ Geochronology and Field Constraints. Journal of Volcanology and Geothermal Research, 189, $19-32$. http://dx.doi.org/10.1016/j.jvolgeores.2009.10.010

[37] Madeira, J., Mata, J., Mourão, C., Brum da Silveira, A., Martins, S., Ramalho, R. and Hoffman, D.L. (2010) VolcanoStratigraphic and Structural Evolution of Brava Island (Cape Verde) Based on ${ }^{40} \mathrm{Ar} /{ }^{39} \mathrm{Ar}$, U-Th and Field Constraints. Journal of Volcanology and Geothermal Research, 196, 219-235. http://dx.doi.org/10.1016/j.jvolgeores.2010.07.010

[38] Montelli, R., Nolet, G., Dahlen, F.A. and Masters, G.A. (2006) Catalogue of Deep Mantle Plumes: New Results from Finite-Frequency Tomography. Geochemistry, Geophysics, Geosystems, 7, Article ID: Q11007.

http://dx.doi.org/10.1029/2006gc001248 